\title{
Dehydrative Cross-Coupling of 1-Phenylethanol Catalyzed by in situ Formed Palladium Nanoparticles Under Acidic Conditions
}

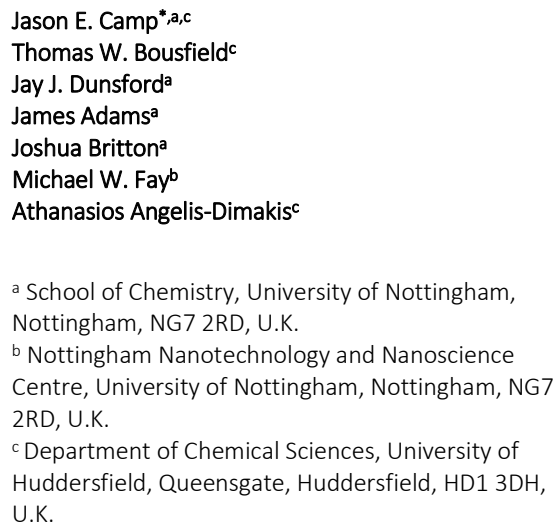

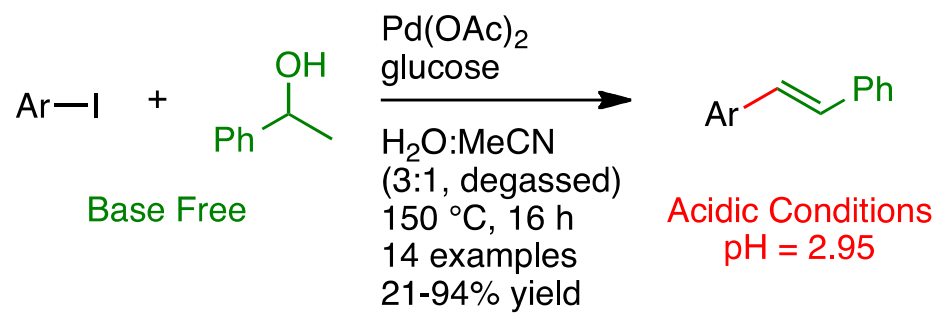

Abstract A dehydrative cross-coupling of 1-phenylethanol catalyzed by sugar derived, in situ formed palladium(0) nanoparticles under acidic conditions is realized. The acidic conditions allow for use of alcohols as a feedstock in metal mediated coupling reactions via their in situ dehydration and subsequent cross-coupling. Extensive analysis of the size and morphology of the in situformed palladium nanoparticles showed that the zero-valent metal was surrounded by hydrophilic hydroxyl groups. EDX-TEM imaging studies using a prototype silicon drift detector provided insight into the problematic role of molecular oxygen in the system. This increased understanding of the catalyst deactivation allowed for the development of the cross-coupling methodology. A 250-12,000 fold increase in molar efficiency was observed when compared to related two-step protocols that use alternative feedstocks for the palladium mediated synthesis of stilbenes. This work opens up a new research area in which the active catalyst is formed, stabilized and regenerated by a renewable sugar.

Key words Glucose, Nanoparticles, Catalysis, Dehydrative Heck, Palladium

Palladium mediated cross-coupling reactions are some of the most powerful methods for the controlled formation of carboncarbon bonds. ${ }^{1}$ Of these, the Mizoroki-Heck reaction is the method of choice for the formation of aryl-alkenyl bonds from the reaction of aryl halides and alkenes. ${ }^{2}$ Since its initial development in the 1970s, the Mizoroki-Heck reaction has been optimized in terms of catalyst, ${ }^{3}$ solvent $^{4}$ and reaction parameters ${ }^{5}$ in order to address limitations of the methodology and expand its substrate scope (Scheme 1a). 6 Two factors that have remained relatively unexamined are the addition of an exogenous base ${ }^{7}$ and the use of alkenes as the feedstock. ${ }^{8}$ For related palladium-catalyzed processes the elimination of exogenous base has been shown to broaden their scope and increase overall sustainability. ${ }^{9}$ In one of the rare instances of using an alternative feedstock in the Mizoroki-Heck reaction, Saiyed and Bedekar showed that benzylbromides, in the presence of excess base, could be used in a domino process to form stilbenes (Scheme $1 \mathrm{~b}$ ). ${ }^{8 \mathrm{a}, 10}$ Importantly, this work eliminated the need to preform and isolate the reactive alkene intermediate. In addition, Colbon et al. recently showed that aryl

Scheme 1. Comparison of feedstocks in the Mizoroki-Heck reaction

a) Typical Mizoroki-Heck reaction

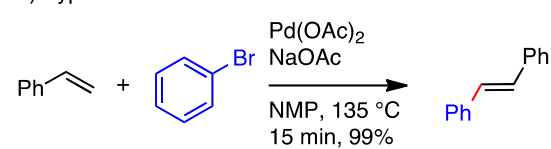

b) Dehalogenative Mizoroki-Heck reaction

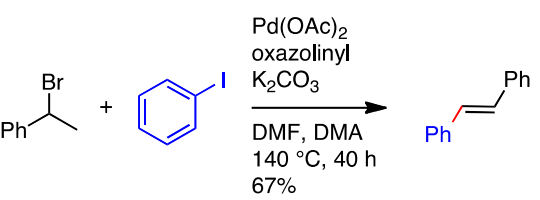

c) Two-step, one-pot dehydrative Mizoroki-Heck reaction

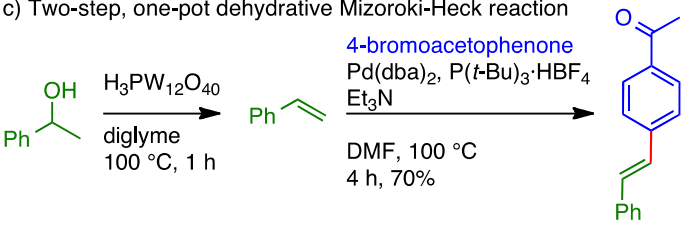

d) This work: Dehydrative cross-coupling under acidic conditions

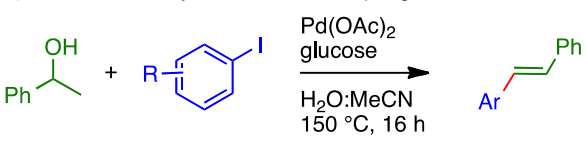


alcohols could be used in a two-step, one-pot process for the in situ generation and reaction of styrenes to form stilbenes (Scheme 1c). ${ }^{11}$ This was accomplished by first reacting the aryl alcohol with a catalytic amount of acid followed by the addition of excess base under Mizoroki-Heck reaction conditions. During the course of our study, Sinha and co-workers used an ionic liquid for the dehydrative-Heck cross-coupling of benzylic alcohols with aryl halides ${ }^{12}$ to form potential anticancer compounds. ${ }^{13}$ This methodology was further extended to include a double dehydrative-Heck process for the synthesis of lead compounds against Alzheimer's disease. ${ }^{14}$ Aryl alcohol 1-phenylethanol (PE) is currently made on an industrial scale as the byproduct of the reaction of ethylbenzene hydroperoxide to form propylene oxide. ${ }^{15}$ The majority of the alcohol is then dehydrated to form styrene. ${ }^{16}$ Whilst styrene is a highly useful reagent, it is inherently unstable and precautions must be taken to prevent rapid exothermic polymerization. ${ }^{17}$ Importantly, the International Agency for Research on Cancer recently classified styrene in Group 2A "probably carcinogenic to humans."18 Therefore, there are key safety, economic and green drivers to develop crosscoupling methods that can eliminate the issues associated with bulk styrene. Previously it was shown that the addition of reducing sugars, such as glucose, to palladium mediated crosscoupling reactions leads to increased yields as well as facile catalyst recycling and increased metal remediation. ${ }^{19,20,21}$ Herein we report a dehydrative cross-coupling of 1-phenylethanol with aryl iodides catalyzed by in situ formed palladium nanoparticles under base free, acidic condition in which the reducing sugars form, stabilize and regenerates the active catalyst (Scheme 1d).

The Mizoroki-Heck reaction between iodobenzene and styrene to form stilbene was used to assess the feasibility of the removal of base (Table 1). It was found that merely removing the base from the previously reported reaction conditions did not afford any of the desired products (Table 1, entries 1 vs. 2). ${ }^{18}$ In order to eliminate the competing oxidation of palladium by molecular oxygen $^{22}$ (vide infra), the solvents were degassed with

Table 1. Development of the Mizoroki-Heck cross-coupling under acidic conditions

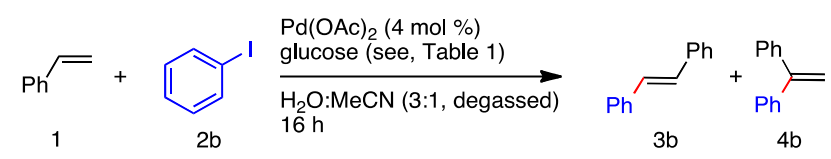

\begin{tabular}{lllll} 
Entry & $\begin{array}{l}\mathrm{Pd} \\
\text { sugar } \\
\text { Ratio }\end{array}$ & $\begin{array}{l}\text { Temp } \\
\left({ }^{\circ} \mathrm{C}\right)\end{array}$ & Yield (\%) & Notes \\
\hline 1 & $1: 2$ & 100 & $97^{a}$ & Ref. 18 \\
2 & $1: 2$ & 100 & 00 & \\
3 & $1: 2$ & 150 & 05 & \\
4 & $1: 10$ & 150 & 41 & \\
5 & $1: 25$ & 150 & 97 & $\mathrm{pH}=2.95$ \\
6 & $1: 50$ & 150 & 40 & \\
7 & $1: 100$ & 150 & 33 & \\
\hline
\end{tabular}

${ }^{a} \mathrm{Et}_{3} \mathrm{~N}$ (1.5 equiv.) was added ${ }^{b} \mathbf{3 b} / \mathbf{4 b}$ were isolated in a ratio of $>90: 10$ nitrogen. ${ }^{23}$ Heating a solution of styrene (1) and iodobenzene (2b) to $150{ }^{\circ} \mathrm{C}$ for $16 \mathrm{~h}$ in the presence of $\mathrm{Pd}(\mathrm{OAc})_{2}$ and glucose gave alkenes $\mathbf{3 b} \mathbf{b} \mathbf{4 b}$ as a 94:6 mixture in excellent yield (Table 2, entry 5). The regiochemical distribution is in line with previously reported high temperature Mizoroki-Heck cross-coupling reactions. ${ }^{24,25}$ The final $\mathrm{pH}$ of this solution was determined to be 2.95. Additionally, it was found that the ratio of sugar to palladium had a substantial effect on the yield of the product with a 1:25 ratio being optimal (Table 2 entries 3-7).

With a better understanding of the acidic cross-coupling reaction in hand, the dehydrative cross-coupling of 1-phenylethanol (5) with 4-iodotoluene (2a) was investigated (Table 2 and Table S3). It was found that the reaction gave the highest yield when 2 equivalents of alcohol $\mathbf{5}$ and 1 equivalent of glucose were used at $150{ }^{\circ} \mathrm{C}$ for $16 \mathrm{~h}$ (Table 2, entry 3). The product alkenes were isolated as an 85:15 mixture of linear 3a to branched isomers $4 \mathbf{a}$. The equivalent of glucose is required to both reduce the palladium and stabilize the in situ formed nanoparticle (vide infra). In order to facilitate the dehydration of 1-phenylethanol (5), acidic additives were screened (Table 2, entries 5-8). The addition of strong acids led to a decreased yield of alkenes $\mathbf{3 a} / \mathbf{4 a}$ (Table 2, entries 5,6). In contrast, the addition of 1.1 equivalents of formic acid resulted in an increase in yield of the desired product to $93 \%$, but had no effect on the isomeric ratio. In contrast, the addition of $10 \mathrm{~mol} \%$ of formic acid gave a deceased yield (Table 2, entry 7 vs. 6). Unfortunately, neither 4bromotoluene nor 4-chlorotoluene afforded any of the desired cross-coupled products and only the starting materials were

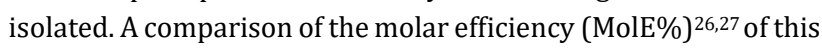
protocol versus related two-step protocols that use alcohols or carboxylic acids for the palladium mediated synthesis of stilbenes showed a 250-12,000 fold increase in efficiency. ${ }^{23}$ Importantly, we have previously shown that in situ formed palladium nanoparticles can readily be recycled without significant loss of catalytic reactivity, which would mitigate the relatively high catalyst loading required in this protocol. ${ }^{19}$

Table 2. Optimization of the dehydrative cross-coupling reaction

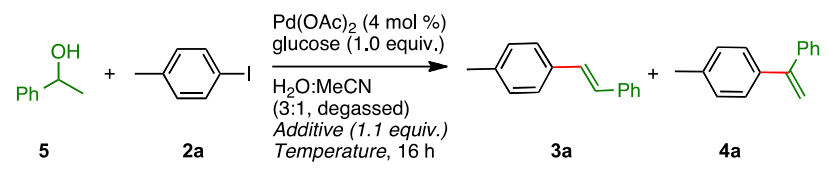

\begin{tabular}{lllll} 
Entry & $\begin{array}{l}\text { Temp } \\
\left({ }^{\circ} \mathrm{C}\right)\end{array}$ & Additive & Ratio 3:4 & Yield (\%) \\
\hline 1 & 130 & - & $85: 15$ & 27 \\
2 & 140 & - & $84: 16$ & 53 \\
3 & 150 & - & $85: 15$ & 83 \\
4 & 150 & $\mathrm{HCl}$ & $87: 13$ & $57^{a}$ \\
5 & 150 & $\mathrm{H}_{2} \mathrm{SO}_{4}$ & $87: 13$ & $16^{a}$ \\
6 & 150 & formic acid & $83: 17$ & $22^{b}$ \\
7 & 150 & formic acid & $84: 16$ & $93^{a}$ \\
\hline
\end{tabular}

a 1.1 equiv. of additive ${ }^{b} 0.1$ equiv. formic acid used

To assess the generality of these conditions, the reaction of 1phenylethanol (5) with a variety of aryl iodides 2 was 
investigated. As there was some ambiguity in the initial study with regard to the use of formic acid in the dehydrative crosscoupling process, the substrate scope investigation was conducted in both its presence and absence (Table 3). For comparison, base free Mizoroki-Heck cross-coupling reactions were also conducted to gain further insights into the dehydrative process (Table S2). Whilst the products were isolated as a mixture of regioisomers $\mathbf{3} / \mathbf{4}$, the ratio of branched to linear was generally $>85: 15$. The reactions of 4-iodotoluene and iodobenzene with 1-phenylethanol (5) in the presence of 4 mol $\%$ palladium acetate and 1 equivalent of glucose proceeded in good yields to form stilbenes $\mathbf{3} \mathbf{a}$ and $\mathbf{3 b}$, respectively. For these substrates, a substantial increase in yield was observed upon the addition of formic acid. The products of the reaction of 1iodonaphthalene, 3c, were formed in good yield under the standard reaction conditions. The addition of formic acid to the reaction of 2-iodotoluene resulted in an increased yield of stilbene 3d. In contrast, the addition of formic acid had little effect on the formation of the more sterically hindered adduct $\mathbf{3 e}$. Electron rich substrate, 4-iodoanisole, was tolerated well under the reaction conditions. Iodobenzenes with electron withdrawing groups afforded the desired cross-coupled adducts 3g-3n in good to excellent yields. In general, formic acid had either a beneficial or negligible effect on the dehydrative crosscoupling reaction, except in cases where additional reactions may have occurred. For example, the nitro group of $(E)$-4-nitro-

Table 3. Substrate scope and role of formic acid in the dehydrative cross-coupling reaction

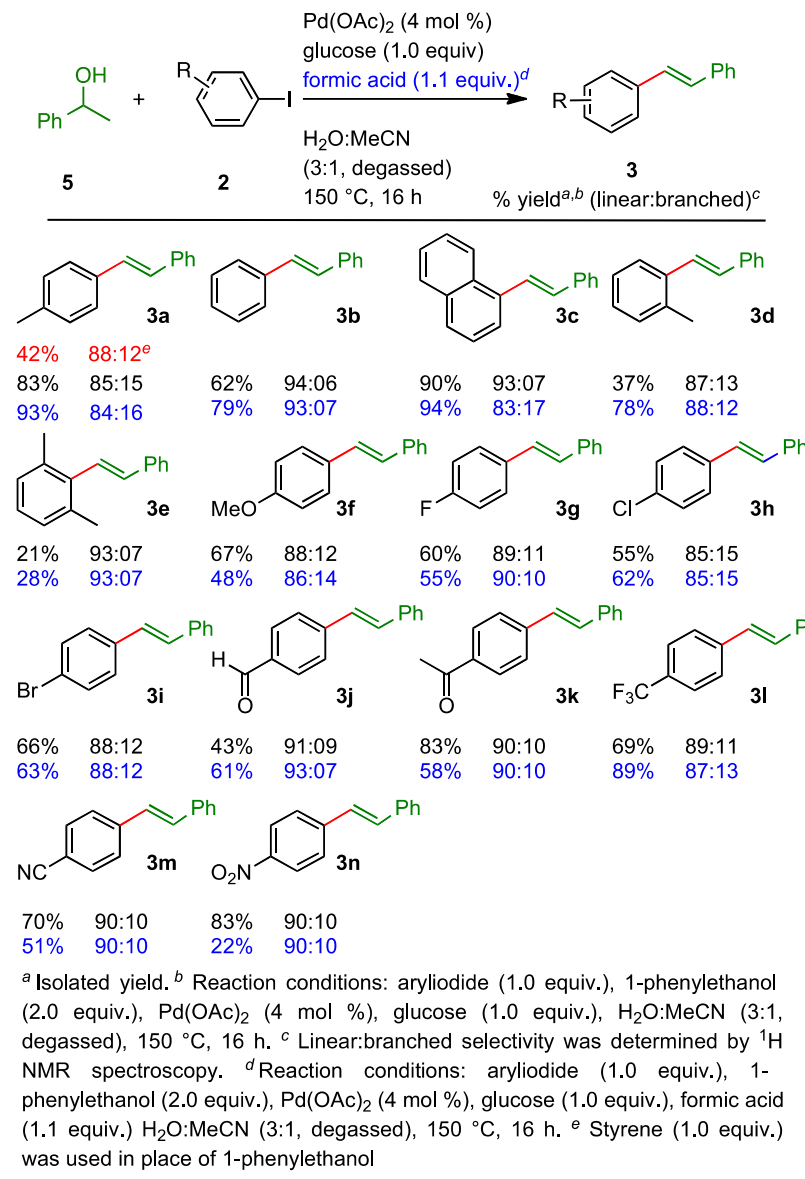

trans-stilbene $\mathbf{3 n}$ could have been reduced under the reaction conditions ${ }^{28}$ whereas the nitrile moiety of $\mathbf{3 m}$ could have been hydrolyzed in the presence of formic acid. Iodoarenes that contained basic nitrogens, such as 4-iodoaniline and 3iodopyridine, did not give any of the desired cross-coupled products $\mathbf{3 / 4}$ under the optimized conditions. This result is in contrast to the related work by Liotta and co-workers, ${ }^{7 a}$ who found that basic nitrogen-containing substrates were required for exogenous base free Suzuki-Miyaura reactions and furthermore highlights the importance of the acidic conditions in our dehydrative cross-coupling protocol.

Transmission Electron Microscopy (TEM) analysis indicated that nanoparticles were formed when the palladium (II) pre-catalyst was subjected to the standard reaction conditions. The less dense amorphous matter at the periphery of the nanoparticles most likely contains the sugar residues (Figure 1a). ${ }^{23}$ Analysis of the sugar-derived nanoparticles suspended in water at room temperature showed that the nanoparticles aggregate into larger clusters of around $100 \mathrm{~nm}$ (Figure 1b). ${ }^{23}$ XPS analysis revealed that the palladium was present only in the zero oxidation state (Figure 1c). ${ }^{23} \mathrm{~A}$ prototype EDX-TEM silicon drift detector was used to determine the amount of carbon and oxygen on the surface of the nanoparticles that were formed in both the absence and presence of oxygen (Figure $1 \mathrm{~d}$ and $1 \mathrm{e}$, respectively). ${ }^{23}$ It was found that there was a statistically significant decrease in the amount of carbon and oxygen on the surface of the nanoparticles that were formed in the presences of oxygen, $5 \%$, versus those that were formed in the absence of oxygen, 37\% (Figure 1f). ${ }^{23}$ This difference in surface coverage is significant because if too little carbon and oxygen are present on the surface of the metal then the catalyst is unreactive ( $c f$. Table 1 ). To the best of our knowledge, this is the first time that a EDX-TEM silicon drift detector has been used to probe the difference in reactivity between in situ formed catalysts.
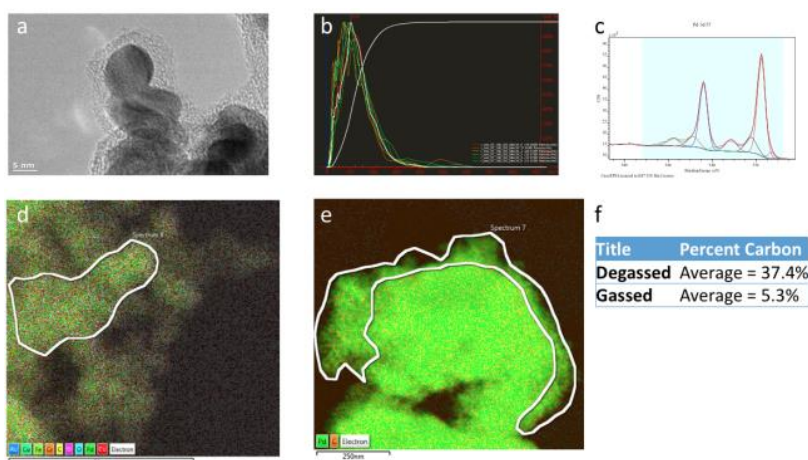

Degassed Average $=37.4 \%$ Gassed Average $=5.3 \%$

Figure 1. (a) TEM analysis (b) Nanosight analysis (c) XPS analysis (d) EDX-TEM analysis of palladium-nanoparticles formed in the absence of molecular oxygen (e) EDX-TEM analysis of palladium-nanoparticles formed in the presence of molecular oxygen (f) Percentage of carbon on the surface of palladiumnanoparticles formed in both the absence and presence of oxygen.

Our mechanistic hypothesis for the dehydrative cross-coupling reaction is predicated on the accepted mechanism for the classical Mizoroki-Heck process ${ }^{2,29}$ as well as the wealth of information on both the formation of metal nanoparticles ${ }^{20,30}$ from reducing sugars and the synthesis of gluconic acid from glucose (Figure 2) ${ }^{31}$ Initially, the palladium(II) precatalyst is reduced by glucose to generate palladium( 0 ) nanoparticles $\left(\mathrm{Pd}^{0} \mathrm{NP}\right)$ with concomitant formation of gluconic acid. ${ }^{19-21}$ The formation of gluconic acid was confirmed by analysis of a 
truncated reaction by mass spectrometry. After this initial oxidation, the gluconic acid can undergo a series of further palladium (II) mediated oxidations to eventually afford carbon dioxide and water, whilst simultaneously releasing additional reducing equivalents. ${ }^{32}$ It is the sequential oxidation of the glucose in combination with the generation of one equivalent of hydrogen iodide per catalytic cycle that makes the aqueous solution acidic, with a final $\mathrm{pH}=2.95$. The acids generated in situ promote the dehydration of 1-phenylethanol (5) to styrene (2). Under the thermal conditions the in situ formed Pd0NPs may be attacked by the arylating agent $\mathbf{1}$ to form a soluble anionic complex. ${ }^{33}$ This species completes the desired Mizoroki-Heck reaction to form cross-coupled products $\mathbf{3 / 4}$, with concomitant generation of a palladium(II) species. The active palladium(0) catalyst can be regenerated via reduction of the palladium(II) species by glucose or an oxidized derivative of glucose. A competing oxidation process involving molecular oxygen can short circuit the catalytic cycle by converting the Pd0NPs to a noncatalytically active palladium(II) species, which would then have to be reduced to re-enter the catalytic cycle. In aerated solvents we believe that the molecular oxygen outcompetes the iodobenzene for the $\mathrm{Pd}^{0} \mathrm{NP}$ catalyst leading to recovery of the starting material. It is believed that an increased temperature of $150{ }^{\circ} \mathrm{C}$ is needed to promote the requisite ring opened conformation of glucose. ${ }^{34}$

Figure 2. Proposed mechanism for the dehydrative crosscoupling reaction

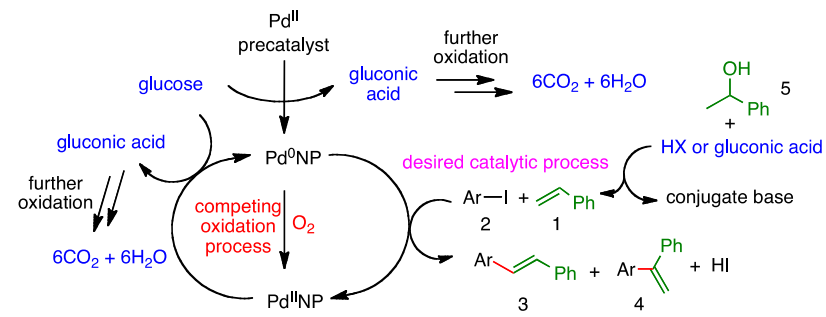

Conclusion - In conclusion, a novel palladium-catalyzed dehydrative cross-coupling protocol for the conversion of 1phenylethanol to di-substituted alkenes was developed. The ability to run the process under acidic conditions and use a secondary aryl alcohol as starting material significantly expands the scope and synthetic utility of the Mizoroki-Heck reaction. The high yields of cross-coupled products were achieved in an aqueous system without the need to preform and isolate the catalyst through the simple addition of a renewable reducing sugar. Mol. E\% calculations showed that the direct dehydrative cross-coupling of 1-phenylethanol was significantly more efficient than previously reported two-step protocols. This work opens up exciting opportunities for the use of reducing sugars to power catalytic reactions, sugar-powered catalysis.

\section{The experimental section has no title; please leave this line here.}

Unless otherwise indicated, all commercially available reagents and solvents were used directly from the supplier without further purification. Acetonitrile and water were degassed by bubbling nitrogen through the solvent at reflux for $1 \mathrm{~h}$. Solvents used for column chromatography were of technical grade. For purification procedures using column chromatography, silica gel (60-120) mesh was used. Thin layer chromatography was carried out using Merck Kieselgel silica gel 60 F254 plates $(0.2 \mathrm{~mm})$ and visualisation was achieved using UV light followed by dipping in a potassium permanganate solution and heating. All reactions were performed in a Biotage $5 \mathrm{~mL}$ microwave vial with Teflon coated cap.
NMR $-{ }^{1} \mathrm{H}$ NMR and ${ }^{13} \mathrm{C}$ NMR were recorded on a Bruker AV400 (400 MHz) spectrometer, Bruker AV(III)400 (400 MHz) spectrometer, Bruker DPX400 $(400 \mathrm{MHz})$ spectrometer or JOEL EX270 $(270 \mathrm{MHz})$ spectrometer at ambient temperature using $\mathrm{CDCl}_{3}$ (7.26 ppm), DMSO-d $(2.50 \mathrm{ppm}),\left(\mathrm{CD}_{3}\right)_{2} \mathrm{CO}$ (2.05 ppm) or $\mathrm{CD}_{3} \mathrm{OD}$ (3.31 ppm) as the solvent. Chemical shift values are expressed as parts per million (ppm) and $J$ values are in Hertz. Splitting patterns are indicated as s: singlet, $d$ : doublet, $t$ : triplet, q: quartet or combination there of, br.s broad singlet or m: multiplet.

FTIR - Solution IR spectra were recorded on a Perkin Elmer 1600 series FTIRspectrophotometer.

Mass Spectrometer - Mass spectra were determined using a Bruker MicroTOF mass spectrometer.

$\mathrm{pH}$ meter - The $\mathrm{pH}$ measurements were recorded on a Philip Harris digital pH meter using a $\mathrm{pH}=7$ standard buffer.

Transmission Electron Microscopy (TEM) - TEM analysis was performed using a JEOL2100F field-emission gun microscope operating at $200 \mathrm{kV}$ and equipped with a Gatan Orius camera. The $\mathrm{Pd}(0)$ nanoparticles were dispersed in water using an ultrasound bath and a suspension $(3.5 \mu \mathrm{L}$ ) was deposited onto a holey carbon grid (Agar Scientific), which had previously been exposed to a low temperature $\mathrm{O}_{2} / \mathrm{Ar}$ plasma for five seconds in a Fischione Model 1020 Plasma Cleaner to make them hydrophilic. TEM image simulations was carried out using spherical aberration coefficient $(C s)=1 \mathrm{~mm}$.

EDX Transmission Electron Microscopy (EDX-TEM) - EDX analysis was performed using a prototype Oxford Instruments Light Element 100mm silicon drift detector on a JEOL $2100 \mathrm{~F}$ operating at $200 \mathrm{kV}$ and the Aztec software. All spectra are acquired from regions not containing amorphous carbon supporting film. $\mathrm{Cr}$, Fe and $\mathrm{Co}$ signals can originate from scatter from the polepiece and holder; Au signal can originate from scatter from the sample holder; Cu signal from the TEM supporting grid has been de-convolved from the quantification.

Nanoparticle Tracking Analysis (NTA) - NTA was performed with a Nanosight LM10HS instrument equipped with an electron multiplication charge coupled device camera mounted on an optical microscope system to track light scattered by particles that are present in a focused $(80 \mu \mathrm{m})$ beam generated by a single mode laser diode with a $60 \mathrm{~mW}$ blue laser illumination $(405 \mathrm{~nm}$ ). The solution containing the palladium(0) nanoparticles in a concentration of between $10^{7}$ and $10^{9}$ particles $/ \mathrm{mL}$ was injected in a sample chamber of $0.5 \mathrm{~mL}$ size from which a volumn of $120 \times 80 \times 20$ microns was visualized under the microscope. The sample concentration was adjusted to ensure statistically significant number of particles under analysis. The Brownian motion of the nanoparticles was tracked at 30 frames/s. NTA 2.2 software was used to evaluate the mean square displacements of each visible particle (calibration $166 \mathrm{~nm} /$ pixel) and from the Strokes-Einstein equation the particle sizes were determined. All experiments were performed without filtering to ensure measurement of all particles. ${ }^{35}$

Dynamic Light Scattering (DLS) - DLS experiments were performed on a Malvern Zetasizer ZS equipped with a He-Ne $(633 \mathrm{~nm}, 5 \mathrm{~mW})$ laser and an Avalanche photodiode detector at an angle of $173^{\circ}$. All DLS data were processed using a Dispersion Technology Software (Malvern Instruments). All experiments were performed without filtering to ensure measurement of all particles. ${ }^{36}$

X-ray Photoelectron Spectroscopy (XPS) - XPS spectra were recorded on the Kratos AXIS ULTRA with a mono-chromated Al ka X-ray source (1486.6eV) operated at $15 \mathrm{~mA}$ emission current and $12 \mathrm{kV}$ anode potential - 180W. Hybrid (magnet/electrostatic) optics (300 × $700 \mu \mathrm{m}$ aperture), hemispherical analyser, multichannel plate and delay line detector (DLD) with a take-off angle of $90^{\circ}$ and an acceptance angle of $30^{\circ}$. All scans were acquired under charge neutralization conditions using a low energy electron gun within the field of magnetic lens. Survey scans were taken with a pass energy of $80 \mathrm{eV}$ and high resolution scans with a pass energy of $20 \mathrm{eV}$. Data analysis is carried out using CASAXPS software with Kratos sensitivity factors to determine atomic \% values from the peak areas.

Scanning Ion Occlusion Sensing (SIOS) - SIOS measurements were carried out on a qNano instrument (Izon Science Ltd., Christchurch, NZ). A standard electrolyte buffer (SEB) of $0.1 \mathrm{M} \mathrm{KCl}, 10 \mathrm{mM}$ Tris buffer, $0.01 \%$ Triton X-100, and 3 mM EDTA, $\mathrm{pH} 8.0$, filtered through a $0.22 \mu \mathrm{m}$ filter was used in all experiments. The membrane was wetted prior to sampling by applying a voltage (typically $0.3 \mathrm{~V}$ ) and manually stretching the pore open (typically with a jaw stretch of $5 \mathrm{~mm}$ ). Once a stable background current achieved, the fluid in the top half of the cell was replaced with a solution of the palladium( 0 ) nanoparticles in the SEB $(30-70 \mu \mathrm{L})$. The magnitude and duration of changes in the current signal were collected at a sampling frequency of $50 \mathrm{kHz}$. The instrument was calibrated using a solution of polystyrene particles (3000 series, $100 \mathrm{~nm}$ ) in SEB. ${ }^{37}$

Procedures 
(E)-1-Methylstilbene ${ }^{38}$ (3a), 1-Methyl-4-(1-phenylvinyl)benzene ${ }^{39}(4 a)$

Method 1: To a stirred solution of $\mathrm{Pd}(\mathrm{OAc})_{2}(3.5 \mathrm{mg}, 0.016 \mathrm{mmol})$ and glucose $(70$ $\mathrm{mg}, 0.39 \mathrm{mmol})$ and 4-iodotoluene $(170 \mathrm{mg}, 0.78 \mathrm{mmol})$ in degassed acetonitrile / degassed water $(1: 3,4 \mathrm{ml})$ at $\mathrm{rt}$ was added styrene $(87 \mu \mathrm{L}, 0.79 \mathrm{mmol})$. The vial was sealed and the mixture was heated at $150^{\circ} \mathrm{C}$ for $16 \mathrm{~h}$. The mixture was cooled to $\mathrm{rt}$ and water $(10 \mathrm{~mL})$ and dichloromethane $(10 \mathrm{~mL})$ were added. The combined organic extracts were dried over $\mathrm{Na}_{2} \mathrm{SO}_{4}$ and the solvent was removed under reduced pressure. The crude residue was purified by flash column chromatography (silica gel, $n$-hexane/EtOAc, 5\%) to give (E)-1-methylstilbene (3a) and 1-Methyl-4-(1phenylvinyl)benzene (4a, $80 \mathrm{mg}$, ratio $88: 12,42 \%$ combined yield) as a white solid.

Method 2: To a stirred solution of $\mathrm{Pd}(\mathrm{OAc})_{2}(3.5 \mathrm{mg}, 0.016 \mathrm{mmol})$, glucose $(70 \mathrm{mg}$, $0.39 \mathrm{mmol}$ ) and 4-iodotoluene $(85 \mathrm{mg}, 0.39 \mathrm{mmol}$ ) in degassed acetonitrile / degassed water $(1: 3,4 \mathrm{~mL})$ at $\mathrm{rt}$ were added 1-phenylethanol $(97 \mathrm{mg}, 0.79 \mathrm{mmol}$ ). The vial was sealed and the mixture was heated at $150^{\circ} \mathrm{C}$ for $16 \mathrm{~h}$. The mixture was cooled to rt and water $(10 \mathrm{~mL})$ and dichloromethane $(10 \mathrm{~mL})$ were added. The combined organic extracts were dried over $\mathrm{Na}_{2} \mathrm{SO}_{4}$ and the solvent was removed under reduced pressure. The crude residue was purified by flash column chromatography (silica gel, $n$-hexane/EtOAc, $5 \%$ ) to give (E)-1-methylstilbene (3a) and 1-Methyl-4-(1-phenylvinyl)benzene (4a, $63 \mathrm{mg}$, ratio 85:15, 83\% combined yield) as a white solid.

Method 3: To a stirred solution of $\mathrm{Pd}(\mathrm{OAc})_{2}(3.5 \mathrm{mg}, 0.016 \mathrm{mmol})$, glucose $(70 \mathrm{mg}$ $0.39 \mathrm{mmol}$ ) and 4-iodotoluene (85 $\mathrm{mg}, 0.39 \mathrm{mmol}$ ) in degassed acetonitrile / degassed water (1:3, $4 \mathrm{~mL}$ ) at $\mathrm{rt}$ were added 1-phenylethanol $(97 \mathrm{mg}, 0.79 \mathrm{mmol}$ ) and formic acid $(33 \mu \mathrm{L}, 0.87 \mathrm{mmol})$. The vial was sealed and the mixture was heated at $150{ }^{\circ} \mathrm{C}$ for $16 \mathrm{~h}$. The mixture was cooled to $\mathrm{rt}$ and water $(10 \mathrm{~mL})$ and dichloromethane $(10 \mathrm{~mL})$ were added. The combined organic extracts were dried over $\mathrm{Na}_{2} \mathrm{SO}_{4}$ and the solvent was removed under reduced pressure. The crude residue was purified by flash column chromatography (silica gel, $n$-hexane/EtOAc, $5 \%$ ) to give (E)-1-methylstilbene (3a) and 1-Methyl-4-(1-phenylvinyl)benzene (4a, 71 $\mathrm{mg}$, ratio $84: 16,93 \%$ combined yield) as a white solid.

(E)-1-Methylstilbene (3a)

${ }^{1} \mathrm{H}$ NMR (400 MHz, $\left.\mathrm{CDCl}_{3}\right): \delta 7.53(\mathrm{~d}, J=7.4 \mathrm{~Hz}, 2 \mathrm{H}), 7.44(\mathrm{~d}, J=8.1 \mathrm{~Hz}, 2 \mathrm{H}), 7.37(\mathrm{t}$, $J=7.6 \mathrm{~Hz}, 2 \mathrm{H}), 7.26(\mathrm{~m}, 1 \mathrm{H}), 7.18(\mathrm{~d}, J=7.9 \mathrm{~Hz}, 2 \mathrm{H}), 7.13(\mathrm{~d}, J=16.4 \mathrm{~Hz}, 1 \mathrm{H}), 7.08$ $(\mathrm{d}, J=16.5 \mathrm{~Hz}, 1 \mathrm{H}), 2.38(\mathrm{~s}, 3 \mathrm{H})$

${ }^{13} \mathrm{C} \mathrm{NMR}\left(100 \mathrm{MHz}, \mathrm{CDCl}_{3}\right) \delta 137.5(2 \times \mathrm{C}), 134.6,129.4(2 \times \mathrm{C}), 128.7(2 \times \mathrm{C}), 128.6$

$127.7,127.4,126.5(2 \times \mathrm{C}), 126.4(2 \times \mathrm{C}), 21.3$

IR $\left(\mathrm{CHCl}_{3}\right): 3020,2915,1593,1508,1493,1448,969,803,706 \mathrm{~cm}^{-1}$

HRMS (APPI) $\mathrm{m} / \mathrm{z}$ calcd. for $\left[\mathrm{C}_{15} \mathrm{H}_{14}\right]^{+}, 194.1090$; found 194.1087.

1-Methyl-4-(1-phenylvinyl)benzene (4a)

${ }^{1} \mathrm{H} \mathrm{NMR}\left(400 \mathrm{MHz}, \mathrm{CDCl}_{3}\right): \delta 7.35-7.32(\mathrm{~m} 5 \mathrm{H}), 7.25(\mathrm{~d}, J=8.1 \mathrm{~Hz}, 2 \mathrm{H}), 7.15(\mathrm{~d}, J=7.9$

$\mathrm{Hz}, 2 \mathrm{H}), 5.44(\mathrm{~d}, J=1.1 \mathrm{~Hz}, 2 \mathrm{H}), 5.41(\mathrm{~d}, J=1.2 \mathrm{~Hz}, 2 \mathrm{H}), 2.38(\mathrm{~s}, 3 \mathrm{H})$

${ }^{13} \mathrm{C} \mathrm{NMR}\left(100 \mathrm{MHz}, \mathrm{CDCl}_{3}\right) \delta 149.9,141.7,138.6,137.5,128.9(2 \times \mathrm{C}), 128.3(2 \times \mathrm{C})$, $128.2(2 \times C), 128.1(2 \times C), 127.6,113.7,21.2$.

$(E)$-Stilbene $e^{40}(3 b), 1,1-D i p h e n y l e t h e n e^{41}(4 b)$

Method 1: To a stirred solution of $\mathrm{Pd}(\mathrm{OAc})_{2}(3.5 \mathrm{mg}, 0.016 \mathrm{mmol})$ and glucose $(70$ $\mathrm{mg}, 0.39 \mathrm{mmol})$ in degassed acetonitrile / degassed water $(1: 3,4 \mathrm{ml})$ at rt were added iodobenzene $(87 \mu \mathrm{L}, 0.78 \mathrm{mmol})$ and styrene $(87 \mu \mathrm{L}, 0.79 \mathrm{mmol})$. The vial was sealed and the mixture was heated at $150{ }^{\circ} \mathrm{C}$ for $16 \mathrm{~h}$. The mixture was cooled to $\mathrm{rt}$ and water $(10 \mathrm{~mL})$ and dichloromethane $(10 \mathrm{~mL})$ were added. The combined organic extracts were dried over $\mathrm{Na}_{2} \mathrm{SO}_{4}$ and the solvent was removed under reduced pressure. The crude residue was purified by flash column chromatography (silica gel, $n$-hexane/EtOAc, $5 \%$ ) to give (E)-stilbene (3b) and 1,1-diphenylethene ( $4 \mathbf{b}$, $136 \mathrm{mg}$, ratio 94:6, 97\% combined yield) as a white solid.

Method 2: To a stirred solution of $\mathrm{Pd}(\mathrm{OAc})_{2}(3.5 \mathrm{mg}, 0.016 \mathrm{mmol})$ and glucose $(70$ $\mathrm{mg}, 0.39 \mathrm{mmol})$ in degassed acetonitrile / degassed water $(1: 3,4 \mathrm{~mL})$ at $\mathrm{rt}$ were added 1-phenylethanol ( $97 \mathrm{mg}, 0.79 \mathrm{mmol}$ ) and iodobenzene $(44 \mu \mathrm{L}, 0.39 \mathrm{mmol}$ ). The vial was sealed and the mixture was heated at $150^{\circ} \mathrm{C}$ for $16 \mathrm{~h}$. The mixture was cooled to rt and water $(10 \mathrm{~mL})$ and dichloromethane $(10 \mathrm{~mL})$ were added. The combined organic extracts were dried over $\mathrm{Na}_{2} \mathrm{SO}_{4}$ and the solvent was removed under reduced pressure. The crude residue was purified by flash column chromatography (silica gel, $n$-hexane/EtOAc, $5 \%$ ) to give (E)-stilbene (3b) and 1,1diphenylethene (4b, $44 \mathrm{mg}$, ratio $94: 6,62 \%$ combined yield) as a white solid.

Method 3: To a stirred solution of $\mathrm{Pd}(\mathrm{OAc})_{2}(3.5 \mathrm{mg}, 0.016 \mathrm{mmol})$ and glucose (70 $\mathrm{mg}, 0.39 \mathrm{mmol})$ in degassed acetonitrile / degassed water $(1: 3,4 \mathrm{~mL})$ at $\mathrm{rt}$ were added 1-phenylethanol ( $97 \mathrm{mg}, 0.79 \mathrm{mmol})$, iodobenzene $(44 \mu \mathrm{L}, 0.39 \mathrm{mmol}$ ) and formic acid ( $33 \mu \mathrm{L}, 0.87 \mathrm{mmol})$. The vial was sealed and the mixture was heated at $150{ }^{\circ} \mathrm{C}$ for $16 \mathrm{~h}$. The mixture was cooled to $\mathrm{rt}$ and water $(10 \mathrm{~mL})$ and dichloromethane $(10 \mathrm{~mL})$ were added. The combined organic extracts were dried over $\mathrm{Na}_{2} \mathrm{SO}_{4}$ and the solvent was removed under reduced pressure. The crude residue was purified by flash column chromatography (silica gel, $n$-hexane/EtOAc, $5 \%)$ to give $(E)$-stilbene $(3 \mathrm{~b})$ and 1,1-diphenylethene (4b, $55 \mathrm{mg}$, ratio 93:7, 79\% combined yield) as a white solid.

(E)-Stilbene (3b) and 1,1-Diphenylethene (4b)

${ }^{1} \mathrm{H} \mathrm{NMR}\left(400 \mathrm{MHz}, \mathrm{CDCl}_{3}\right): \delta 7.60-7.58(\mathrm{~m}, 4 \mathrm{H}), 7.45-7.39(\mathrm{~m}, 5.57 \mathrm{H}), 7.35-7.31(\mathrm{~m}$, $2 \mathrm{H}), 7.18(\mathrm{~s}, 2 \mathrm{H}), 5.54(\mathrm{~s}, 0.26 \mathrm{H})$

${ }^{13} \mathrm{C} \mathrm{NMR}$ (stillbene) $\left(100 \mathrm{MHz}, \mathrm{CDCl}_{3}\right) \delta 137.4,128.8,127.7,126.6$; IR $\left(\mathrm{CHCl}_{3}\right): 3021$, 2915, 1494, 1451, 983, 808, $688 \mathrm{~cm}^{-1}$

HRMS (APPI) $\mathrm{m} / \mathrm{z}$ calcd. for $\mathrm{C}_{14} \mathrm{H}_{12}, 180.0934$; found 180.0932 .

(E)-1-StyryInaphthalene ${ }^{42}$ (3c), 1-(1-Phenylethenyl)naphthalene ${ }^{43}(4 \mathrm{c})$

Method 2: To a stirred solution of $\mathrm{Pd}(\mathrm{OAc})_{2}(3.5 \mathrm{mg}, 0.016 \mathrm{mmol})$ and glucose (70 $\mathrm{mg}, 0.39 \mathrm{mmol})$ in degassed acetonitrile / degassed water $(1: 3,4 \mathrm{~mL})$ at rt were added 1-phenylethanol $(97 \mathrm{mg}, 0.79 \mathrm{mmol}$ ) and 1-iodonaphthalene $(57 \mu \mathrm{L}, 0.78$ $\mathrm{mmol})$. The vial was sealed and the mixture was heated at $150{ }^{\circ} \mathrm{C}$ for $16 \mathrm{~h}$. The mixture was cooled to $\mathrm{rt}$ and water $(10 \mathrm{~mL})$ and dichloromethane $(10 \mathrm{~mL})$ were added. The combined organic extracts were dried over $\mathrm{Na}_{2} \mathrm{SO}_{4}$ and the solvent was removed under reduced pressure. The crude residue was purified by flash column chromatography (silica gel, $n$-hexane/EtOAc, $5 \%$ ) to give $(E)$-1-styrylnaphthalene (3c) and 1-(1-phenylethenyl)naphthalene (4c, $45 \mathrm{mg}$, ratio 93:17, 90\% combined yield) as a colourless oil.

Method 3: To a stirred solution of $\mathrm{Pd}(\mathrm{OAc})_{2}(3.5 \mathrm{mg}, 0.016 \mathrm{mmol})$ and glucose (70 $\mathrm{mg}, 0.39 \mathrm{mmol})$ in degassed acetonitrile / degassed water $(1: 3,4 \mathrm{~mL})$ at $\mathrm{rt}$ were added 1-phenylethanol ( $97 \mathrm{mg}, 0.79 \mathrm{mmol}), 1$-iodonaphthalene $(57 \mu \mathrm{L}, 0.78 \mathrm{mmol}$ ) and formic acid $(33 \mu \mathrm{L}, 0.87 \mathrm{mmol})$. The vial was sealed and the mixture was heated at $150{ }^{\circ} \mathrm{C}$ for $16 \mathrm{~h}$. The mixture was cooled to $\mathrm{rt}$ and water $(10 \mathrm{~mL})$ and dichloromethane $(10 \mathrm{~mL})$ were added. The combined organic extracts were dried over $\mathrm{Na}_{2} \mathrm{SO}_{4}$ and the solvent was removed under reduced pressure. The crude residue was purified by flash column chromatography (silica gel, $n$-hexane/EtOAc, $5 \%$ ) to give (E)-1-styrylnaphthalene (3c) and 1-(1-phenylethenyl)naphthalene (4c, 85 $\mathrm{mg}$, ratio $83: 17,94 \%$ combined yield) as a colourless oil.

(E)-1-Styrylnaphthalene (3c)

${ }^{1} \mathrm{H} \mathrm{NMR}\left(500 \mathrm{MHz}, \mathrm{CDCl}_{3}\right): \delta 8.25(\mathrm{~d}, J=8.3 \mathrm{~Hz}, 1 \mathrm{H}), 7.93-7.88(\mathrm{~m}, 2 \mathrm{H}), 7.83(\mathrm{~d}, J=$ $8.2 \mathrm{~Hz}, 1 \mathrm{H}), 7.77(\mathrm{~d}, J=7.1 \mathrm{~Hz}, 1 \mathrm{H}), 7.63(\mathrm{~d}, J=7.3 \mathrm{~Hz}, 2 \mathrm{H}), 7.58-7.50(\mathrm{~m}, 3 \mathrm{H}), 7.43$ $(\mathrm{t}, J=7.7 \mathrm{~Hz}, 3 \mathrm{H}), 7.34-7.31(\mathrm{~m}, 1 \mathrm{H}), 7.18(\mathrm{~d}, J=16.0 \mathrm{~Hz}, 1 \mathrm{H})$

${ }^{13} \mathrm{C} \mathrm{NMR}\left(100 \mathrm{MHz}, \mathrm{CDCl}_{3}\right) \delta 137.7,135.1,133.8,131.8,131.4,128.8(2 \times \mathrm{C}), 128.7$, $128.1,127.8,126.7(2 \times \mathrm{C}), 126.1,125.9,125.8,125.7,123.8,123.5$ IR $\left(\mathrm{CHCl}_{3}\right): 3056,2928,2852,1493,1263,959,774,734,692 \mathrm{~cm}^{-1}$ HRMS (APPI) $(\mathrm{m} / \mathrm{z})$ calcd. for $\left[\mathrm{C}_{18} \mathrm{H}_{14}\right]^{+}, 230.1090$; found 230.1089 .

1-(1-Phenylethenyl)naphthalene (4c)

${ }^{1} \mathrm{H} \mathrm{NMR}\left(500 \mathrm{MHz}, \mathrm{CDCl}_{3}\right): \delta 7.86,7.84(\mathrm{~m} \mathrm{2H}), 7.77-7.75(\mathrm{~m}, 1 \mathrm{H}), 7.51-7.48(\mathrm{~m}, 1 \mathrm{H})$, 7.44-7.41 (m, 2H), 7.34-7.30 (m, 3H), 7.27-7.24 (m, 3H), $5.98(\mathrm{~d}, J=1.4 \mathrm{~Hz}, 2 \mathrm{H}), 5.39$ (d, J $=1.4 \mathrm{~Hz}, 2 \mathrm{H})$

${ }^{13} \mathrm{C} \mathrm{NMR}\left(100 \mathrm{MHz}, \mathrm{CDCl}_{3}\right) \delta 148.3,141.1,139.8,133.7,131.9,128.4(2 \times \mathrm{C}), 128.2$, $128.0,127.7,127.2,126.6(2 \times C), 126.4,125.9,125.7,125.4,116.3$.

(E)-2-Methylstilbene ${ }^{44}$ (3d), 1-Methyl-2-(1-phenylvinyl)benzene ${ }^{45}$ (4d)

Method 1: To a stirred solution of $\mathrm{Pd}(\mathrm{OAc})_{2}(3.5 \mathrm{mg}, 0.016 \mathrm{mmol})$ and glucose (70 $\mathrm{mg}, 0.39 \mathrm{mmol})$ in degassed acetonitrile / degassed water (1:3, $4 \mathrm{ml}$ ) at rt were added 2-iodotoluene $(99 \mu \mathrm{L}, 0.78 \mathrm{mmol}$ ) and styrene $(99 \mu \mathrm{L}, 0.79 \mathrm{mmol})$. The vial was sealed and the mixture was heated at $150{ }^{\circ} \mathrm{C}$ for $16 \mathrm{~h}$. The mixture was cooled to $\mathrm{rt}$ and water $(10 \mathrm{~mL})$ and dichloromethane $(10 \mathrm{~mL})$ were added. The combined organic extracts were dried over $\mathrm{Na}_{2} \mathrm{SO}_{4}$ and the solvent was removed under reduced pressure. The crude residue was purified by flash column chromatography 
(silica gel, $n$-hexane/EtOAc, 5\%) to give (E)-2-methylstilbene (3d) and 1-methyl-2-(1phenylvinyl)benzene $(4 \mathrm{~d}, 71 \mathrm{mg}$, ratio $88: 12,47 \%$ combined yield) as a colourless oil.

Method 2: To a stirred solution of $\mathrm{Pd}(\mathrm{OAc})_{2}(3.5 \mathrm{mg}, 0.016 \mathrm{mmol})$ and glucose $(70$ $\mathrm{mg}, 0.39 \mathrm{mmol})$ in degassed acetonitrile / degassed water $(1: 3,4 \mathrm{~mL})$ at $\mathrm{rt}$ were added 1-phenylethanol ( $97 \mathrm{mg}, 0.79 \mathrm{mmol}$ ) and 2-iodotoluene $(50 \mu \mathrm{L}, 0.39 \mathrm{mmol})$. The vial was sealed and the mixture was heated at $150{ }^{\circ} \mathrm{C}$ for $16 \mathrm{~h}$. The mixture was cooled to $\mathrm{rt}$ and water $(10 \mathrm{~mL})$ and dichloromethane $(10 \mathrm{~mL})$ were added. The combined organic extracts were dried over $\mathrm{Na}_{2} \mathrm{SO}_{4}$ and the solvent was removed under reduced pressure. The crude residue was purified by flash column chromatography (silica gel, $n$-hexane/EtOAc, $5 \%$ ) to give $(E)$-2-methylstilbene (3d) and 1-methyl-2-(1-phenylvinyl)benzene (4d, $28 \mathrm{mg}$, ratio 87:13, 37\% combined yield) as a colourless oil.

Method 3: To a stirred solution of $\mathrm{Pd}(\mathrm{OAc})_{2}(3.5 \mathrm{mg}, 0.016 \mathrm{mmol})$ and glucose (70 $\mathrm{mg}, 0.39 \mathrm{mmol})$ in degassed acetonitrile / degassed water $(1: 3,4 \mathrm{~mL})$ at rt were added 1-phenylethanol (97 mg, $0.79 \mathrm{mmol}), 2$-iodotoluene $(50 \mu \mathrm{L}, 0.39 \mathrm{mmol})$ and formic acid ( $33 \mu \mathrm{L}, 0.87 \mathrm{mmol})$. The vial was sealed and the mixture was heated at $150{ }^{\circ} \mathrm{C}$ for $16 \mathrm{~h}$. The mixture was cooled to $\mathrm{rt}$ and water $(10 \mathrm{~mL})$ and dichloromethane $(10 \mathrm{~mL})$ were added. The combined organic extracts were dried over $\mathrm{Na}_{2} \mathrm{SO}_{4}$ and the solvent was removed under reduced pressure. The crude residue was purified by flash column chromatography (silica gel, $n$-hexane/EtOAc, $5 \%)$ to give $(E)$-2-methylstilbene $3 \mathrm{~d}$ and 1-methyl-2-(1-phenylvinyl)benzene $4 \mathrm{~d}$ (59 $\mathrm{mg}$, ratio $88: 12,78 \%$ combined yield) as a colourless oil.

\section{(E)-2-Methylstilbene (3d)}

${ }^{1} \mathrm{H} \mathrm{NMR}\left(400 \mathrm{MHz}, \mathrm{CDCl}_{3}\right): \delta 7.65(\mathrm{~d}, J=7.1 \mathrm{~Hz}, 1 \mathrm{H}), 7.58(\mathrm{~d}, J=7.5 \mathrm{~Hz}, 2 \mathrm{H}), 7.41(\mathrm{t}$ $J=7.6 \mathrm{~Hz}, 3 \mathrm{H}), 7.37-7.23,(\mathrm{~m}, 5 \mathrm{H}), 7.06(\mathrm{~d}, J=16.2 \mathrm{~Hz}, 1 \mathrm{H}), 2.49(\mathrm{~s}, 3 \mathrm{H})$

${ }^{13} \mathrm{C} \mathrm{NMR}\left(100 \mathrm{MHz}, \mathrm{CDCl}_{3}\right) \delta 137.8,136.5,135.9,130.5,130.1,128.8(2 \times \mathrm{C}), 127.7$, $127.6,126.64(2 \times C), 126.61,126.3,125.4,20.0$

IR $\left(\mathrm{CHCl}_{3}\right): 3023,2923,1540,1494,959,756,711 \mathrm{~cm}^{-1}$

HRMS (APPI) $\mathrm{m} / \mathrm{z}$ calcd. for $\left[\mathrm{C}_{15} \mathrm{H}_{14}\right]^{+}, 194.1090$; found 194.1088

1-Methyl-2-(1-phenylvinyl)benzene (4d)

${ }^{1} \mathrm{H}$ NMR $\left(400 \mathrm{MHz}, \mathrm{CDCl}_{3}\right): \delta 7.32-7.17(\mathrm{~m}, 9 \mathrm{H}), 5.77(\mathrm{~d}, J=1.3 \mathrm{~Hz}, 1 \mathrm{H}), 5.22(\mathrm{~d}, J=$ $1.3 \mathrm{~Hz}, 1 \mathrm{H}), 2.05(\mathrm{~s}, 3 \mathrm{H})$

${ }^{13} \mathrm{C} \mathrm{NMR}\left(100 \mathrm{MHz}, \mathrm{CDCl}_{3}\right) \delta 137.8,136.5,130.5,130.1,128.8(2 \times \mathrm{C}), 127.7,127.6$, $126.64(2 \times C), 126.61,126.3,125.4,20.0$

\section{(E)-2,6-Dimethylstilbene ${ }^{46}$ (3e), 1,3-Dimethyl-2-(1-phenylvinyl)benzene ${ }^{46}(4 \mathrm{e})$}

Method 2: To a stirred solution of $\mathrm{Pd}(\mathrm{OAc})_{2}(3.5 \mathrm{mg}, 0.016 \mathrm{mmol})$ and glucose $(70$ $\mathrm{mg}, 0.39 \mathrm{mmol})$ in degassed acetonitrile / degassed water $(1: 3,4 \mathrm{~mL})$ at $\mathrm{rt}$ were added 1-phenylethanol (97 mg, $0.79 \mathrm{mmol}$ ) and 2-iodo-1,3-dimethylbenzene (57 $\mu \mathrm{L}, 0.39 \mathrm{mmol})$. The vial was sealed and the mixture was heated at $150^{\circ} \mathrm{C}$ for $16 \mathrm{~h}$. The mixture was cooled to $\mathrm{rt}$ and water $(10 \mathrm{~mL})$ and dichloromethane $(10 \mathrm{~mL})$ were added. The combined organic extracts were dried over $\mathrm{Na}_{2} \mathrm{SO}_{4}$ and the solvent was removed under reduced pressure. The crude residue was purified by flash column chromatography (silica gel, $n$-hexane/EtOAc, $5 \%$ ) to give (E)-2,6-dimethylstilbene (3e) and 1,3-dimethyl-2-(1-phenylvinyl)benzene (4e, $17 \mathrm{mg}$, ratio 93:7, 21\% combined yield) as a colourless oil.

Method 3: To a stirred solution of $\mathrm{Pd}(\mathrm{OAc})_{2}(3.5 \mathrm{mg}, 0.016 \mathrm{mmol})$ and glucose (70 $\mathrm{mg}, 0.39 \mathrm{mmol})$ in degassed acetonitrile / degassed water $(1: 3,4 \mathrm{~mL})$ at $\mathrm{rt}$ were added 1-phenylethanol (97 mg, $0.79 \mathrm{mmol}), 2$-iodo-1,3-dimethylbenzene $(57 \mu \mathrm{L}$, $0.39 \mathrm{mmol}$ ) and formic acid $(33 \mu \mathrm{L}, 0.87 \mathrm{mmol})$. The vial was sealed and the mixture was heated at $150^{\circ} \mathrm{C}$ for $16 \mathrm{~h}$. The mixture was cooled to $\mathrm{rt}$ and water $(10 \mathrm{~mL})$ and dichloromethane $(10 \mathrm{~mL})$ were added. The combined organic extracts were dried over $\mathrm{Na}_{2} \mathrm{SO}_{4}$ and the solvent was removed under reduced pressure. The crude residue was purified by flash column chromatography (silica gel, $n$-hexane/EtOAc, $5 \%$ ) to give (E)-2,6-dimethylstilbene (3e) and 1,3-dimethyl-2-(1-phenylvinyl)benzene (4e, $23 \mathrm{mg}$, ratio $93: 7,28 \%$ combined yield) as a colourless oil.

\section{(E)-2,6-Dimethylstilbene (3e)}

${ }^{1} \mathrm{H} \mathrm{NMR}\left(400 \mathrm{MHz}, \mathrm{CDCl}_{3}\right): \delta 7.54(\mathrm{~d}, J=7.3 \mathrm{~Hz}, 2 \mathrm{H}), 7.40(\mathrm{t}, J=7.9 \mathrm{~Hz}, 2 \mathrm{H}), 7.31(\mathrm{t}, J$ $=7.3 \mathrm{~Hz}, 1 \mathrm{H}), 7.17-7.11(\mathrm{~m}, 4 \mathrm{H}), 6.64(\mathrm{~d}, J=16.8 \mathrm{~Hz}, 1 \mathrm{H}), 2.40(\mathrm{~s}, 6 \mathrm{H})$
${ }^{13} \mathrm{C} \mathrm{NMR}\left(100 \mathrm{MHz}, \mathrm{CDCl}_{3}\right) \delta 137.6,137.0,136.3(2 \times \mathrm{C}), 134.0,128.7(2 \times \mathrm{C}), 127.7$ $(2 \times \mathrm{C}), 127.6,127.0,126.8,126.3(2 \times \mathrm{C}), 21.1(2 \times \mathrm{C})$ IR $\left(\mathrm{CHCl}_{3}\right): 3023,2922,2853,1595,1464,968,766,690 \mathrm{~cm}^{-1}$ HRMS (APPI) $\mathrm{m} / \mathrm{z}$ calcd. for $\left[\mathrm{C}_{16} \mathrm{H}_{16}\right]^{+}, 208.1247$; found 208.1248

(E)-4-Methoxystilbene ${ }^{47}$ (3f), 1-Methoxy-4-(1-phenylvinyl)benzene ${ }^{47}$ (4f)

Method 1: To a stirred solution of $\mathrm{Pd}(\mathrm{OAc})_{2}(3.5 \mathrm{mg}, 0.016 \mathrm{mmol})$ and glucose (70 $\mathrm{mg}, 0.39 \mathrm{mmol}$ ) and 4-iodoanisole (183 $\mathrm{mg}, 0.78 \mathrm{mmol})$ in degassed acetonitrile / degassed water $(1: 3,4 \mathrm{ml})$ at $\mathrm{rt}$ was added styrene $(87 \mu \mathrm{L}, 0.79 \mathrm{mmol})$. The vial was sealed and the mixture was heated at $150{ }^{\circ} \mathrm{C}$ for $16 \mathrm{~h}$. The mixture was cooled to rt and water $(10 \mathrm{~mL})$ and dichloromethane $(10 \mathrm{~mL})$ were added. The combined organic extracts were dried over $\mathrm{Na}_{2} \mathrm{SO}_{4}$ and the solvent was removed under reduced pressure. The crude residue was purified by flash column chromatography (silica gel, $n$-hexane/EtOAc, 5\%) to give (E)-1-methoxystilbene (3f) and 1-methoxy-4-(1phenylvinyl)benzene (4f, $152 \mathrm{mg}$, ratio $84: 16,93 \%$ combined yield) as a white solid.

Method 2: To a stirred solution of $\mathrm{Pd}(\mathrm{OAc})_{2}(3.5 \mathrm{mg}, 0.016 \mathrm{mmol})$, glucose $(70 \mathrm{mg}$, $0.39 \mathrm{mmol}$ ) and 4-iodoanisole (91 $\mathrm{mg}, 0.39 \mathrm{mmol}$ ) in degassed acetonitrile / degassed water $(1: 3,4 \mathrm{~mL})$ at rt were added 1-phenylethanol $(97 \mathrm{mg}, 0.79 \mathrm{mmol}$ ). The vial was sealed and the mixture was heated at $150^{\circ} \mathrm{C}$ for $16 \mathrm{~h}$. The mixture was cooled to $\mathrm{rt}$ and water $(10 \mathrm{~mL})$ and dichloromethane $(10 \mathrm{~mL})$ were added. The combined organic extracts were dried over $\mathrm{Na}_{2} \mathrm{SO}_{4}$ and the solvent was removed under reduced pressure. The crude residue was purified by flash column chromatography (silica gel, $n$-hexane/EtOAc, $5 \%$ ) to give $(E)$-1-methoxystilbene (3f) and 1-methoxy-4-(1-phenylvinyl)benzene (4f, $64 \mathrm{mg}$, ratio 88:12, 67\% combined yield) as a white solid.

Method 3: To a stirred solution of $\mathrm{Pd}(\mathrm{OAc})_{2}(3.5 \mathrm{mg}, 0.016 \mathrm{mmol})$, glucose $(70 \mathrm{mg}$, $0.39 \mathrm{mmol}$ ) and 4-iodoanisole (91 $\mathrm{mg}, 0.39 \mathrm{mmol}$ ) in degassed acetonitrile / degassed water $(1: 3,4 \mathrm{~mL})$ at $\mathrm{rt}$ were added 1-phenylethanol $(97 \mathrm{mg}, 0.79 \mathrm{mmol}$ ) and formic acid $(33 \mu \mathrm{L}, 0.87 \mathrm{mmol})$. The vial was sealed and the mixture was heated at $150{ }^{\circ} \mathrm{C}$ for $16 \mathrm{~h}$. The mixture was cooled to $\mathrm{rt}$ and water $(10 \mathrm{~mL})$ and dichloromethane $(10 \mathrm{~mL})$ were added. The combined organic extracts were dried over $\mathrm{Na}_{2} \mathrm{SO}_{4}$ and the solvent was removed under reduced pressure. The crude residue was purified by flash column chromatography (silica gel, $n$-hexane/EtOAc, $5 \%$ ) to give (E)-1-methoxystilbene (3f) and 1-methoxy-4-(1-phenylvinyl)benzene (4f, $43 \mathrm{mg}$, ratio $86: 14,48 \%$ combined yield) as a white solid.

(E)-1-Methoxystilbene (3f)

${ }^{1} \mathrm{H} \mathrm{NMR}\left(400 \mathrm{MHz}, \mathrm{CDCl}_{3}\right): \delta 7.53-7.48(\mathrm{~m}, 3 \mathrm{H}), 7.37(\mathrm{t}, J=7.6 \mathrm{~Hz}, 2 \mathrm{H}), 7.28-7.22(\mathrm{~m}$, $2 \mathrm{H}), 7.10(\mathrm{~d}, J=16.3 \mathrm{~Hz}, 1 \mathrm{H}), 7.00(\mathrm{~d}, J=16.3 \mathrm{~Hz}, 1 \mathrm{H}), 6.93(\mathrm{~d}, J=8.7 \mathrm{~Hz}, 2 \mathrm{H}), 3.86$ $(\mathrm{s}, 3 \mathrm{H})$

${ }^{13} \mathrm{CNMR}\left(100 \mathrm{MHz}, \mathrm{CDCl}_{3}\right) \delta 159.3,137.7,130.2,128.7(2 \times \mathrm{C}), 128.2,127.7(2 \times \mathrm{C})$ 127.2, 126.6, $126.3(2 \times \mathrm{C}), 114.1(2 \times \mathrm{C}), 55.3$ IR $\left(\mathrm{CHCl}_{3}\right): 3022,3002,2933,2836,1600,1508,1266,1028,811,686 \mathrm{~cm}^{-1}$ HRMS (APPI) $\mathrm{m} / \mathrm{z}$ calcd. for $\left[\mathrm{C}_{15} \mathrm{H}_{14} \mathrm{O}\right]^{+}, 210.1039$; found 210.1039 .

(E)-4-Fluorostilbene ${ }^{44}(3 \mathrm{~g}), 1$-Fluoro-4-(phenylvinyl)benzene ${ }^{43}(\mathbf{4 g})$

Method 1: To a stirred solution of $\mathrm{Pd}(\mathrm{OAc})_{2}(3.5 \mathrm{mg}, 0.016 \mathrm{mmol})$ and glucose (70 $\mathrm{mg}, 0.39 \mathrm{mmol})$ in degassed acetonitrile / degassed water $(1: 3,4 \mathrm{ml})$ at rt were added 4-fluoroiodobenzene $(90 \mu \mathrm{L}, 0.78 \mathrm{mmol})$ and styrene $(87 \mu \mathrm{L}, 0.79 \mathrm{mmol})$. The vial was sealed and the mixture was heated at $150{ }^{\circ} \mathrm{C}$ for $16 \mathrm{~h}$. The mixture was cooled to $\mathrm{rt}$ and water $(10 \mathrm{~mL})$ and dichloromethane $(10 \mathrm{~mL})$ were added. The combined organic extracts were dried over $\mathrm{Na}_{2} \mathrm{SO}_{4}$ and the solvent was removed under reduced pressure. The crude residue was purified by flash column chromatography (silica gel, $n$-hexane/EtOAc, $5 \%$ ) to give $(E)$-4-fluorostilbene $(3 \mathrm{~g}$ ) and 1-fluoro-4-(1-phenylvinyl)benzene (4g, $83 \mathrm{mg}$, ratio 94:6, 54\% combined yield) as a white solid.

Method 2: To a stirred solution of $\mathrm{Pd}(\mathrm{OAc})_{2}(3.5 \mathrm{mg}, 0.016 \mathrm{mmol})$ and glucose (70 $\mathrm{mg}, 0.39 \mathrm{mmol})$ in degassed acetonitrile / degassed water $(1: 3,4 \mathrm{~mL})$ at rt were added 1-phenylethanol $(97 \mathrm{mg}, 0.79 \mathrm{mmol}$ ) and 4-fluoroiodobenzene $(45 \mu \mathrm{L}, 0.39$ mmol). The vial was sealed and the mixture was heated at $150{ }^{\circ} \mathrm{C}$ for $16 \mathrm{~h}$. The mixture was cooled to $\mathrm{rt}$ and water $(10 \mathrm{~mL})$ and dichloromethane $(10 \mathrm{~mL})$ were added. The combined organic extracts were dried over $\mathrm{Na}_{2} \mathrm{SO}_{4}$ and the solvent was removed under reduced pressure. The crude residue was purified by flash column chromatography (silica gel, $n$-hexane/EtOAc, $5 \%$ ) to give (E)-4-fluorostilbene (3g) 
and 1-fluoro-4-(1-phenylvinyl)benzene (4g, $60 \mathrm{mg}$, ratio 89:11, 60\% combined yield) as a white solid.

Method 3: To a stirred solution of $\mathrm{Pd}(\mathrm{OAc})_{2}(3.5 \mathrm{mg}, 0.016 \mathrm{mmol})$ and glucose $(70$ $\mathrm{mg}, 0.39 \mathrm{mmol})$ in degassed acetonitrile / degassed water $(1: 3,4 \mathrm{~mL})$ at rt were added 1-phenylethanol (97 mg, $0.79 \mathrm{mmol}), 4$-fluoroiodobenzene $(45 \mu \mathrm{L}, 0.39$ $\mathrm{mmol}$ ) and formic acid ( $33 \mu \mathrm{L}, 0.87 \mathrm{mmol})$. The vial was sealed and the mixture was heated at $150{ }^{\circ} \mathrm{C}$ for $16 \mathrm{~h}$. The mixture was cooled to $\mathrm{rt}$ and water $(10 \mathrm{~mL})$ and dichloromethane $(10 \mathrm{~mL})$ were added. The combined organic extracts were dried over $\mathrm{Na}_{2} \mathrm{SO}_{4}$ and the solvent was removed under reduced pressure. The crude residue was purified by flash column chromatography (silica gel, $n$-hexane/EtOAc, $5 \%)$ to give (E)-4-fluoro-trans-stilbene (3g) and 1-fluoro-4-(1-phenylvinyl)benzene (4g, $42 \mathrm{mg}$, ratio 90:10, 55\% combined yield) as a white solid.

(E)-4-Fluorostilbene (3g)

${ }^{1} \mathrm{H}$ NMR $\left(400 \mathrm{MHz}, \mathrm{CDCl}_{3}\right): \delta 7.53-7.48(\mathrm{~m}, 4 \mathrm{H}), 7.39(\mathrm{t}, J=7.6 \mathrm{~Hz}, 2 \mathrm{H}), 7.29(\mathrm{t}, J=$ $7.30 \mathrm{~Hz}, 1 \mathrm{H}), 7.12-7.02(\mathrm{~m}, 4 \mathrm{H})$

${ }^{13} \mathrm{C} \mathrm{NMR}\left(100 \mathrm{MHz}, \mathrm{CDCl}_{3}\right) \delta 162.4(\mathrm{~d}, J=246.3 \mathrm{~Hz}), 137.2,133.5(\mathrm{~d}, J=3.4 \mathrm{~Hz})$, $128.7,128.5(\mathrm{~d}, J=2.4 \mathrm{~Hz}), 128.0(\mathrm{~d}, J=8.0 \mathrm{~Hz}), 127.7,127.5,126.5,115.6(\mathrm{~d}, J=$ $21.7 \mathrm{~Hz})$

${ }^{19} \mathrm{~F} \mathrm{NMR}\left(376 \mathrm{MHz}, \mathrm{CDCl}_{3}\right) \delta-114.2(\mathrm{~s}, 1 \mathrm{~F})$

IR $\left(\mathrm{CHCl}_{3}\right): 3022,2923,2851,1592,1504,1226,999,822,751 \mathrm{~cm}^{-1}$

HRMS (APPI) $\mathrm{m} / \mathrm{z}$ calcd. for $\mathrm{C}_{14} \mathrm{H}_{12}, 198.0839$; found 198.0835 .

(E)-1-Chloro-4-styrylbenzene ${ }^{40}$ (3h), 1-Chloro-4-(1-phenylvinyl)benzene ${ }^{41}$ (4h)

Method 2: To a stirred solution of $\mathrm{Pd}(\mathrm{OAc})_{2}(3.5 \mathrm{mg}, 0.016 \mathrm{mmol})$, glucose $(70 \mathrm{mg}$, $0.39 \mathrm{mmol}$ ) and 4-chloroiodotoluene ( $93 \mathrm{mg}, 0.39 \mathrm{mmol}$ ) in degassed acetonitrile / degassed water (1:3, $4 \mathrm{~mL}$ ) at rt were added 1-phenylethanol $(97 \mathrm{mg}, 0.79 \mathrm{mmol}$ ). The vial was sealed and the mixture was heated at $150{ }^{\circ} \mathrm{C}$ for $16 \mathrm{~h}$. The mixture was cooled to rt and water $(10 \mathrm{~mL})$ and dichloromethane $(10 \mathrm{~mL})$ were added. The combined organic extracts were dried over $\mathrm{Na}_{2} \mathrm{SO}_{4}$ and the solvent was removed under reduced pressure. The crude residue was purified by flash column chromatography (silica gel, $n$-hexane/EtOAc, $5 \%$ ) to give $(E)$-1-chloro-4styrylbenzene (3h) and 1-chloro-4-(1-phenylvinyl)benzene (4h, $46 \mathrm{mg}$, ratio 85:15, $55 \%$ combined yield) as a white solid.

Method 3: To a stirred solution of $\mathrm{Pd}(\mathrm{OAc})_{2}(3.5 \mathrm{mg}, 0.016 \mathrm{mmol})$, glucose $(70 \mathrm{mg}$, $0.39 \mathrm{mmol}$ ) and 4-chloroiodotoluene ( $93 \mathrm{mg}, 0.39 \mathrm{mmol})$ in degassed acetonitrile / degassed water (1:3, $4 \mathrm{~mL}$ ) at rt were added 1-phenylethanol $(97 \mathrm{mg}, 0.79 \mathrm{mmol}$ ) and formic acid $(33 \mu \mathrm{L}, 0.87 \mathrm{mmol})$. The vial was sealed and the mixture was heated at $150{ }^{\circ} \mathrm{C}$ for $16 \mathrm{~h}$. The mixture was cooled to $\mathrm{rt}$ and water $(10 \mathrm{~mL})$ and dichloromethane $(10 \mathrm{~mL})$ were added. The combined organic extracts were dried over $\mathrm{Na}_{2} \mathrm{SO}_{4}$ and the solvent was removed under reduced pressure. The crude residue was purified by flash column chromatography (silica gel, $n$-hexane/EtOAc, $5 \%)$ to give (E)-1-chloro-4-styrylbenzene (3h) and 1-chloro-4-(1phenylvinyl)benzene (4h, $52 \mathrm{mg}$, ratio $85: 15,62 \%$ combined yield) as a white solid.

(E)-1-Chloro-4-styrylbenzene (3h)

${ }^{1} \mathrm{H} \mathrm{NMR}\left(400 \mathrm{MHz}, \mathrm{CDCl}_{3}\right): \delta 7.52(\mathrm{~d}, J=7.4 \mathrm{~Hz}, 2 \mathrm{H}), 7.45(\mathrm{~d}, J=8.5 \mathrm{~Hz}, 2 \mathrm{H}), 7.40$ $7.27(\mathrm{~m}, 5 \mathrm{H}), 7.12-7.03(\mathrm{~m}, 2 \mathrm{H})$

${ }^{13} \mathrm{C} \mathrm{NMR}\left(100 \mathrm{MHz}, \mathrm{CDCl}_{3}\right) \delta 137.0,135.9,133.2,129.3,128.9(2 \times \mathrm{C}), 128.8(2 \times \mathrm{C})$ $127.9,127.7(2 \times \mathrm{C}), 127.4,126.6(2 \times \mathrm{C})$ IR $\left(\mathrm{CHCl}_{3}\right): 3055,2987,2928,1558,1540,1264,730,701,669 \mathrm{~cm}^{-1}$

GCMS (EI) $\mathrm{m} / \mathrm{z}$ calcd. for $\left[\mathrm{C}_{14} \mathrm{H}_{11} \mathrm{Cl}\right]^{+}, 214.1$; found 214.0 .

1-Chloro-4-(1-phenylvinyl)benzene (4h)

${ }^{1} \mathrm{H}$ NMR $\left(400 \mathrm{MHz}, \mathrm{CDCl}_{3}\right): \delta 7.33-7.26(\mathrm{~m} \mathrm{1OH}), 5.47(\mathrm{~s}, 1 \mathrm{H}), 5.45(\mathrm{~s}, 1 \mathrm{H})$ ${ }^{13} \mathrm{C} \mathrm{NMR}\left(100 \mathrm{MHz}, \mathrm{CDCl}_{3}\right) \delta 149.0,141.02,140.0,133.6,129.6(2 \times \mathrm{C}), 128.4(2 \times \mathrm{C})$, $128.3(2 \times C), 128.2(2 \times C), 237.9,114.7$.

(E)-4-Bromostilbene ${ }^{48}$ (3i), 1-(4-Bromophenyl)-1-phenylethene ${ }^{49}(4 \mathbf{i})$

Method 1: To a stirred solution of $\mathrm{Pd}(\mathrm{OAc})_{2}(3.5 \mathrm{mg}, 0.016 \mathrm{mmol})$, glucose (70 mg, $0.39 \mathrm{mmol}$ ) and 4-iodobromobenzene $(221 \mathrm{mg}, 0.78 \mathrm{mmol})$ in degassed acetonitrile / degassed water $(1: 3,4 \mathrm{ml})$ at $\mathrm{rt}$ were added styrene $(87 \mu \mathrm{L}, 0.79 \mathrm{mmol})$. The vial was sealed and the mixture was heated at $150^{\circ} \mathrm{C}$ for $16 \mathrm{~h}$. The mixture was cooled to $\mathrm{rt}$ and water $(10 \mathrm{~mL})$ and dichloromethane $(10 \mathrm{~mL})$ were added. The combined organic extracts were dried over $\mathrm{Na}_{2} \mathrm{SO}_{4}$ and the solvent was removed under reduced pressure. The crude residue was purified by flash column chromatography (silica gel, $n$-hexane/EtOAc, 5\%) to give (E)-4-bromo-stilbene (3i) and 1-bromo-4-(1phenylvinyl)benzene (4i, $176 \mathrm{mg}$, ratio $86: 14,87 \%$ combined yield) as a white solid.

Method 2: To a stirred solution of $\mathrm{Pd}(\mathrm{OAc})_{2}(3.5 \mathrm{mg}, 0.016 \mathrm{mmol})$, glucose $(70 \mathrm{mg}$, $0.39 \mathrm{mmol})$ and 4-iodobromobenzene $(110 \mathrm{mg}, 0.39 \mathrm{mmol})$ in degassed acetonitrile / degassed water (1:3, $4 \mathrm{~mL}$ ) at rt were added 1-phenylethanol $(97 \mathrm{mg}, 0.79 \mathrm{mmol}$ ). The vial was sealed and the mixture was heated at $150^{\circ} \mathrm{C}$ for $16 \mathrm{~h}$. The mixture was cooled to $\mathrm{rt}$ and water $(10 \mathrm{~mL})$ and dichloromethane $(10 \mathrm{~mL})$ were added. The combined organic extracts were dried over $\mathrm{Na}_{2} \mathrm{SO}_{4}$ and the solvent was removed under reduced pressure. The crude residue was purified by flash column chromatography (silica gel, $n$-hexane/EtOAc, $5 \%$ ) to give $(E)$-4-bromostilbene (3i) and 1-bromo-4-(1-phenylvinyl)benzene (4i, $67 \mathrm{mg}$, ratio $88: 12,66 \%$ combined yield) as a white solid.

Method 3: To a stirred solution of $\mathrm{Pd}(\mathrm{OAc})_{2}(3.5 \mathrm{mg}, 0.016 \mathrm{mmol})$, glucose $(70 \mathrm{mg}$, $0.39 \mathrm{mmol})$ and 4-iodobromobenzene $(110 \mathrm{mg}, 0.39 \mathrm{mmol})$ in degassed acetonitrile / degassed water (1:3, $4 \mathrm{~mL}$ ) at rt were added 1-phenylethanol ( $97 \mathrm{mg}, 0.79 \mathrm{mmol}$ ) and formic acid $(33 \mu \mathrm{L}, 0.87 \mathrm{mmol})$. The vial was sealed and the mixture was heated at $150{ }^{\circ} \mathrm{C}$ for $16 \mathrm{~h}$. The mixture was cooled to $\mathrm{rt}$ and water $(10 \mathrm{~mL})$ and dichloromethane $(10 \mathrm{~mL}$ ) were added. The combined organic extracts were dried over $\mathrm{Na}_{2} \mathrm{SO}_{4}$ and the solvent was removed under reduced pressure. The crude residue was purified by flash column chromatography (silica gel, $n$-hexane/EtOAc, $5 \%$ ) to give (E)-4-bromostilbene (3i) and 1-bromo-4-(1-phenylvinyl)benzene (4i, 64 $\mathrm{mg}$, ratio $88: 12,63 \%$ combined yield) as a white solid.

(E)-4-Bromostilbene (3i)

${ }^{1} \mathrm{H} \mathrm{NMR}\left(400 \mathrm{MHz}, \mathrm{CDCl}_{3}\right): \delta 7.53-7.46(\mathrm{~m}, 4 \mathrm{H}), 7.40-7.34(\mathrm{~m}, 4 \mathrm{H}), 7.30-7.25(\mathrm{~m}, 1 \mathrm{H})$, 7.07 (dd, $J=16.4 \mathrm{~Hz}, J=28.3 \mathrm{~Hz}, 2 \mathrm{H}$ )

${ }^{13} \mathrm{C} \mathrm{NMR}\left(100 \mathrm{MHz}, \mathrm{CDCl}_{3}\right) \delta 137.0,136.3,131.8,129.4,128.8,128.0,127.9,127.4$, 126.6, 121.3

IR $\left(\mathrm{CHCl}_{3}\right): 3025,2921,2852,1485,1072,964,840,688 \mathrm{~cm}^{-1}$ HRMS (APPI) $\mathrm{m} / \mathrm{z}$ calcd. for $\left[\mathrm{C}_{14} \mathrm{H}_{11} \mathrm{Br}\right]^{+}, 258.0039$; found 258.0029 .

(E)-4-Styrylbenzaldehyde ${ }^{50}$ (3j), 4-(1-Phenylvinyl)benzaldehyde ${ }^{43}$ (4j)

Method 1: To a stirred solution of $\mathrm{Pd}(\mathrm{OAc})_{2}(3.5 \mathrm{mg}, 0.016 \mathrm{mmol})$ and glucose (70 $\mathrm{mg}, 0.39 \mathrm{mmol})$ and 4-iodobenzaldehyde (170 $\mathrm{mg}, 0.78 \mathrm{mmol})$ in degassed acetonitrile / degassed water $(1: 3,4 \mathrm{ml})$ at $\mathrm{rt}$ was added styrene $(87 \mu \mathrm{L}, 0.79 \mathrm{mmol})$. The vial was sealed and the mixture was heated at $150^{\circ} \mathrm{C}$ for $16 \mathrm{~h}$. The mixture was cooled to $\mathrm{rt}$ and water $(10 \mathrm{~mL})$ and dichloromethane $(10 \mathrm{~mL})$ were added. The combined organic extracts were dried over $\mathrm{Na}_{2} \mathrm{SO}_{4}$ and the solvent was removed under reduced pressure. The crude residue was purified by flash column chromatography (silica gel, $n$-hexane/EtOAc, $5 \%$ ) to give (E)-4-styrylbenzaldehyde (3j) and 4-(1-phenylvinyl)benzaldehyde (4j, $63 \mathrm{mg}$, ratio 90:10, 39\% combined yield) as a white solid.

Method 2: To a stirred solution of $\mathrm{Pd}(\mathrm{OAc})_{2}(3.5 \mathrm{mg}, 0.016 \mathrm{mmol})$, glucose $(70 \mathrm{mg}$, $0.39 \mathrm{mmol}$ ) and 4-iodobenzaldehyde $(85 \mathrm{mg}, 0.39 \mathrm{mmol})$ in degassed acetonitrile / degassed water $(1: 3,4 \mathrm{~mL})$ at $\mathrm{rt}$ were added 1-phenylethanol $(97 \mathrm{mg}, 0.79 \mathrm{mmol})$. The vial was sealed and the mixture was heated at $150^{\circ} \mathrm{C}$ for $16 \mathrm{~h}$. The mixture was cooled to $\mathrm{rt}$ and water $(10 \mathrm{~mL})$ and dichloromethane $(10 \mathrm{~mL})$ were added. The combined organic extracts were dried over $\mathrm{Na}_{2} \mathrm{SO}_{4}$ and the solvent was removed under reduced pressure. The crude residue was purified by flash column chromatography (silica gel, $n$-hexane/EtOAc, $5 \%$ ) to give (E)-4-styrylbenzaldehyde (3j) and 4-(1-phenylvinyl)benzaldehyde (4j, $35 \mathrm{mg}$, ratio 91:9, 43\% combined yield) as a white solid.

Method 3: To a stirred solution of $\mathrm{Pd}(\mathrm{OAc})_{2}(3.5 \mathrm{mg}, 0.016 \mathrm{mmol})$, glucose $(70 \mathrm{mg}$, $0.39 \mathrm{mmol}$ ) and 4-iodobenzaldehyde $(85 \mathrm{mg}, 0.39 \mathrm{mmol})$ in degassed acetonitrile / degassed water $(1: 3,4 \mathrm{~mL})$ at $\mathrm{rt}$ were added 1-phenylethanol $(97 \mathrm{mg}, 0.79 \mathrm{mmol}$ ) and formic acid $(33 \mu \mathrm{L}, 0.87 \mathrm{mmol})$. The vial was sealed and the mixture was heated at $150{ }^{\circ} \mathrm{C}$ for $16 \mathrm{~h}$. The mixture was cooled to $\mathrm{rt}$ and water $(10 \mathrm{~mL})$ and dichloromethane $(10 \mathrm{~mL})$ were added. The combined organic extracts were dried over $\mathrm{Na}_{2} \mathrm{SO}_{4}$ and the solvent was removed under reduced pressure. The crude residue was purified by flash column chromatography (silica gel, $n$-hexane/EtOAc, $5 \%)$ to give $(E)$-4-styrylbenzaldehyde ( $3 \mathbf{j})$ and 4-(1-phenylvinyl)benzaldehyde (4j, 50 $\mathrm{mg}$, ratio $93: 7,61 \%$ combined yield) as a white solid. 


\section{(E)-4-Styrylbenzaldehyde (3j)}

${ }^{1} \mathrm{H}$ NMR (400 MHz, CDCl $)$ ): $\delta 10.00(\mathrm{~s}, 1 \mathrm{H}), 7.87(\mathrm{~d}, J=8.2 \mathrm{~Hz}, 2 \mathrm{H}), 7.66(\mathrm{~d}, J=8.1 \mathrm{~Hz}$ $2 \mathrm{H}), 7.55(\mathrm{~d}, J=7.5 \mathrm{~Hz}, 2 \mathrm{H}), 7.40(\mathrm{t}, J=7.5 \mathrm{~Hz}, 2 \mathrm{H}), 7.34-7.25(\mathrm{~m}, 2 \mathrm{H}), 7.15(\mathrm{t}, J=$ $16.4 \mathrm{~Hz}, 1 \mathrm{H})$

${ }^{13} \mathrm{C} \mathrm{NMR}\left(100 \mathrm{MHz}, \mathrm{CDCl}_{3}\right) \delta 191.6,143.4,136.6,135.3,132.2,130.3,128.9,128.5$, $127.3,126.9(2 \times \mathrm{C})$

IR $\left(\mathrm{CHCl}_{3}\right): 3028,2820,2729,1692,1590,1209,1166,968,816,759,688 \mathrm{~cm}^{-1}$ HRMS (Dual ESI) $\mathrm{m} / \mathrm{z}$ calcd. for $\left[\mathrm{C}_{15} \mathrm{H}_{13} \mathrm{O}\right]^{+}, 209.0961$; found 209.0961 .

(E)-1-(4-Styrylphenyl)ethan-1-one ${ }^{48}$ (3k), 1-(4-(1-Phenylvinyl)phenyl)ethan-1-one ${ }^{51}$ $(4 \mathrm{k})$

Method 1: To a stirred solution of $\mathrm{Pd}(\mathrm{OAc})_{2}(3.5 \mathrm{mg}, 0.016 \mathrm{mmol})$ and glucose $(70$ $\mathrm{mg}, 0.39 \mathrm{mmol})$ and 4-iodotoluene $(170 \mathrm{mg}, 0.78 \mathrm{mmol}$ ) in degassed acetonitrile / degassed water $(1: 3,4 \mathrm{ml})$ at $\mathrm{rt}$ was added styrene $(87 \mu \mathrm{L}, 0.79 \mathrm{mmol})$. The vial was sealed and the mixture was heated at $150^{\circ} \mathrm{C}$ for $16 \mathrm{~h}$. The mixture was cooled to rt and water $(10 \mathrm{~mL})$ and dichloromethane $(10 \mathrm{~mL})$ were added. The combined organic extracts were dried over $\mathrm{Na}_{2} \mathrm{SO}_{4}$ and the solvent was removed under reduced pressure. The crude residue was purified by flash column chromatography (silica gel, $n$-hexane/EtOAc, 5\%) to give (E)-1-(4-styrylphenyl)ethan-1-one (3k) and 1-(4-(1phenylvinyl)phenyl)ethan-1-one ( $4 \mathrm{k}, 78 \mathrm{mg}$, ratio $93: 7,45 \%$ combined yield) as a white solid.

Method 2: To a stirred solution of $\mathrm{Pd}(\mathrm{OAc})_{2}(3.5 \mathrm{mg}, 0.016 \mathrm{mmol})$, glucose $(70 \mathrm{mg}$, $0.39 \mathrm{mmol})$ and 4-iodotoluene $(85 \mathrm{mg}, 0.39 \mathrm{mmol})$ in degassed acetonitrile / degassed water $(1: 3,4 \mathrm{~mL})$ at rt were added 1-phenylethanol $(97 \mathrm{mg}, 0.79 \mathrm{mmol}$ ). The vial was sealed and the mixture was heated at $150{ }^{\circ} \mathrm{C}$ for $16 \mathrm{~h}$. The mixture was cooled to rt and water $(10 \mathrm{~mL})$ and dichloromethane $(10 \mathrm{~mL})$ were added. The combined organic extracts were dried over $\mathrm{Na}_{2} \mathrm{SO}_{4}$ and the solvent was removed under reduced pressure. The crude residue was purified by flash column chromatography (silica gel, $n$-hexane/EtOAc, $5 \%$ ) to give (E)-1-(4styrylphenyl)ethan-1-one (3k) and 1-(4-(1-phenylvinyl)phenyl)ethan-1-one (4k, 50 $\mathrm{mg}$, ratio 90:10, 83\% combined yield) as a white solid.

Method 3: To a stirred solution of $\mathrm{Pd}(\mathrm{OAc})_{2}(3.5 \mathrm{mg}, 0.016 \mathrm{mmol})$, glucose $(70 \mathrm{mg}$, $0.39 \mathrm{mmol}$ ) and 4-iodotoluene (85 $\mathrm{mg}, 0.39 \mathrm{mmol}$ ) in degassed acetonitrile / degassed water $(1: 3,4 \mathrm{~mL}$ ) at $\mathrm{rt}$ were added 1-phenylethanol (97 $\mathrm{mg}, 0.79 \mathrm{mmol}$ ) and formic acid $(33 \mu \mathrm{L}, 0.87 \mathrm{mmol})$. The vial was sealed and the mixture was heated at $150{ }^{\circ} \mathrm{C}$ for $16 \mathrm{~h}$. The mixture was cooled to $\mathrm{rt}$ and water $(10 \mathrm{~mL})$ and dichloromethane $(10 \mathrm{~mL})$ were added. The combined organic extracts were dried over $\mathrm{Na}_{2} \mathrm{SO}_{4}$ and the solvent was removed under reduced pressure. The crude residue was purified by flash column chromatography (silica gel, $n$-hexane/EtOAc, $5 \%)$ to give (E)-1-(4-styrylphenyl)ethan-1-one (3k) and 1-(4-(1phenylvinyl)phenyl)ethan-1-one ( $4 \mathrm{k}, 50 \mathrm{mg}$, ratio $90: 10,58 \%$ combined yield) as a white solid.

\section{(E)-1-(4-Styrylphenyl)ethan-1-one (3k)}

${ }^{1} \mathrm{H}$ NMR (400 MHz, $\left.\mathrm{CDCl}_{3}\right): \delta 7.96(\mathrm{~d}, J=8.3 \mathrm{~Hz}, 2 \mathrm{H}), 7.59(\mathrm{~d}, J=8.3 \mathrm{~Hz}, 2 \mathrm{H}), 7.54(\mathrm{~d}$, $J=7.5 \mathrm{~Hz}, 2 \mathrm{H}), 7.39(\mathrm{t}, J=7.5 \mathrm{~Hz}, 2 \mathrm{H}), 7.33-7.29(\mathrm{~m}, 1 \mathrm{H}), 7.26-7.22(\mathrm{~m}, 1 \mathrm{H}), 7.14(\mathrm{~d}$, $J=16.4 \mathrm{~Hz}, 1 \mathrm{H}), 2.61(\mathrm{~s}, 3 \mathrm{H})$

${ }^{13} \mathrm{C} \mathrm{NMR}\left(100 \mathrm{MHz}, \mathrm{CDCl}_{3}\right) \delta 197.5,136.7,136.0,131.5,128.9(2 \times \mathrm{C}), 128.8(2 \times \mathrm{C})$, $128.3,127.5,126.8(2 \times C), 126.5(2 \times C), 26.6$

IR $\left(\mathrm{CHCl}_{3}\right): 3010,2922,2853,1673,1633,1410,1356,1260,999,843,753,688,610$ $\mathrm{cm}^{-1}$

HRMS (APPI) $\mathrm{m} / \mathrm{z}$ calcd. for $\left[\mathrm{C}_{16} \mathrm{H}_{14} \mathrm{O}\right]^{+}, 222.1039$; found 222.1039 .

(E)-4-Trifluoromethylstilbene ${ }^{40}$ (3I), 1-(1-Phenylvinyl)-4-trifluoromethyl)benzene ${ }^{41}$ (4I)

Method 1: To a stirred solution of $\mathrm{Pd}(\mathrm{OAc})_{2}(3.5 \mathrm{mg}, 0.016 \mathrm{mmol})$ and glucose $(70$ $\mathrm{mg}, 0.39 \mathrm{mmol})$ in degassed acetonitrile / degassed water $(1: 3,4 \mathrm{ml})$ at rt were added 4-iodobenzotrifluoride $(114 \mu \mathrm{L}, 0.78 \mathrm{mmol})$ and styrene $(87 \mu \mathrm{L}, 0.79 \mathrm{mmol})$. The vial was sealed and the mixture was heated at $150{ }^{\circ} \mathrm{C}$ for $16 \mathrm{~h}$. The mixture was cooled to rt and water $(10 \mathrm{~mL})$ and dichloromethane $(10 \mathrm{~mL})$ were added. The combined organic extracts were dried over $\mathrm{Na}_{2} \mathrm{SO}_{4}$ and the solvent was removed under reduced pressure. The crude residue was purified by flash column chromatography (silica gel, $n$-hexane/EtOAc, 5\%) to give (E)-4- trifluoromethylstilbene (3I) and 1-(1-phenylvinyl)-4-(trifluoromethyl)benzene (4I, $172 \mathrm{mg}$, ratio $87: 13,89 \%$ combined yield) as a white solid.

Method 2: To a stirred solution of $\mathrm{Pd}(\mathrm{OAc})_{2}(3.5 \mathrm{mg}, 0.016 \mathrm{mmol})$ and glucose (70 $\mathrm{mg}, 0.39 \mathrm{mmol})$ in degassed acetonitrile / degassed water $(1: 3,4 \mathrm{~mL})$ at rt were added 1-phenylethanol $(97 \mathrm{mg}, 0.79 \mathrm{mmol})$ and 4-iodobenzotrifluoride $(57 \mu \mathrm{L}, 0.78$ mmol). The vial was sealed and the mixture was heated at $150{ }^{\circ} \mathrm{C}$ for $16 \mathrm{~h}$. The mixture was cooled to $\mathrm{rt}$ and water $(10 \mathrm{~mL})$ and dichloromethane $(10 \mathrm{~mL})$ were added. The combined organic extracts were dried over $\mathrm{Na}_{2} \mathrm{SO}_{4}$ and the solvent was removed under reduced pressure. The crude residue was purified by flash column chromatography (silica gel, $n$-hexane/EtOAc, $5 \%$ ) to give (E)-4trifluoromethylstilbene (3I) and 1-(1-phenylvinyl)-4-(trifluoromethyl)benzene (4I, 67 $\mathrm{mg}$, ratio $89: 11,69 \%$ combined yield) as a white solid.

Method 3: To a stirred solution of $\mathrm{Pd}(\mathrm{OAc})_{2}(3.5 \mathrm{mg}, 0.016 \mathrm{mmol})$ and glucose (70 $\mathrm{mg}, 0.39 \mathrm{mmol})$ in degassed acetonitrile / degassed water $(1: 3,4 \mathrm{~mL})$ at rt were added 1-phenylethanol (97 mg, $0.79 \mathrm{mmol}), 4$-iodobenzotrifluoride $(57 \mu \mathrm{L}, 0.78$ $\mathrm{mmol})$ and formic acid $(33 \mu \mathrm{L}, 0.87 \mathrm{mmol})$. The vial was sealed and the mixture was heated at $150{ }^{\circ} \mathrm{C}$ for $16 \mathrm{~h}$. The mixture was cooled to rt and water $(10 \mathrm{~mL})$ and dichloromethane $(10 \mathrm{~mL})$ were added. The combined organic extracts were dried over $\mathrm{Na}_{2} \mathrm{SO}_{4}$ and the solvent was removed under reduced pressure. The crude residue was purified by flash column chromatography (silica gel, $n$-hexane/EtOAc, $5 \%)$ to give (E)-4-trifluoromethylstilbene (3I) and 1-(1-phenylvinyl)-4(trifluoromethyl)benzene $(4 \mathrm{l}, 86 \mathrm{mg}$, ratio $87: 13,89 \%$ combined yield) as a white solid.

\section{(E)-4-Trifluoromethylstilbene (3I)}

${ }^{1} \mathrm{H} \mathrm{NMR}\left(400 \mathrm{MHz}, \mathrm{CDCl}_{3}\right): \delta 7.64-7.59(\mathrm{~m}, 4 \mathrm{H}), 7.55(\mathrm{~d}, J=7.04 \mathrm{~Hz}, 2 \mathrm{H}), 7.41(\mathrm{t}, J=$ $7.48 \mathrm{~Hz}, 2 \mathrm{H}), 7.33(\mathrm{t}, J=7.28 \mathrm{~Hz}, 1 \mathrm{H}), 7.21(\mathrm{~d}, J=16.4 \mathrm{~Hz}, 1 \mathrm{H}), 7.13(\mathrm{~d}, J=16.3 \mathrm{~Hz}$, $1 \mathrm{H})$

${ }^{13} \mathrm{C} \mathrm{NMR}\left(100 \mathrm{MHz}, \mathrm{CDCl}_{3}\right) \delta 140.8,136.6,131.2,129.7,129.4,129.1,128.8,127.1$, $126.8,126.6,125.7$ (q, $2 \times \mathrm{C}), 122.9,123.2$

$\left.{ }^{19} \mathrm{~F} \mathrm{NMR} \mathrm{(376} \mathrm{MHz}, \mathrm{CDCl}_{3}\right) \delta-62.4$ (s, 3F); IR $\left(\mathrm{CHCl}_{3}\right): 3028,2928,2854,1612,1450$, $1321,1164,1105,1066,843,756,692 \mathrm{~cm}^{-1}$

HRMS (APPI) $\mathrm{m} / \mathrm{z}$ calcd. for $\left[\mathrm{C}_{15} \mathrm{H}_{11} \mathrm{~F}_{3}\right]^{+}, 248.0807$; found 248.0809 .

1-(1-Phenylvinyl)-4-(trifluoromethyl)benzene (4I)

${ }^{1} \mathrm{H} \mathrm{NMR}\left(400 \mathrm{MHz}, \mathrm{CDCl}_{3}\right): \delta 7.62(\mathrm{~d}, J=8.2 \mathrm{~Hz}, 2 \mathrm{H}), 7.47(\mathrm{~d}, J=8.1 \mathrm{~Hz}, 2 \mathrm{H}), 7.39-$ $7.32(\mathrm{~m}, 5 \mathrm{H}), 5.58(\mathrm{~s}, 1 \mathrm{H}), 5.54(\mathrm{~s}, 1 \mathrm{H})$

${ }^{13} \mathrm{C} \mathrm{NMR}\left(100 \mathrm{MHz}, \mathrm{CDCl}_{3}\right) \delta 149.0,140.6,128.8,128.6(2 \times \mathrm{C}), 128.4(2 \times \mathrm{C}), 128.2$ $(2 \times \mathrm{C}), 128.1,126.8,126.6,125.2(\mathrm{q}, 2 \times \mathrm{C}), 115.9$

${ }^{19} \mathrm{~F} \mathrm{NMR}\left(376 \mathrm{MHz}, \mathrm{CDCl}_{3}\right) \delta-62.5(\mathrm{~s}, 3 \mathrm{~F})$.

(E)-4-Styrylbenzonitrile ${ }^{40}(3 \mathrm{~m}), 4-(1-P h e n y l v i n y l)$ benzonitrile ${ }^{45}(4 \mathrm{~m})$

Method 2: To a stirred solution of $\mathrm{Pd}(\mathrm{OAc})_{2}(3.5 \mathrm{mg}, 0.016 \mathrm{mmol})$, glucose $(70 \mathrm{mg}$, $0.39 \mathrm{mmol}$ ) and 4-iodotoluene (85 $\mathrm{mg}, 0.39 \mathrm{mmol})$ in degassed acetonitrile / degassed water (1:3, $4 \mathrm{~mL}$ ) at $\mathrm{rt}$ were added 1-phenylethanol $(97 \mathrm{mg}, 0.79 \mathrm{mmol}$ ). The vial was sealed and the mixture was heated at $150^{\circ} \mathrm{C}$ for $16 \mathrm{~h}$. The mixture was cooled to $\mathrm{rt}$ and water $(10 \mathrm{~mL})$ and dichloromethane $(10 \mathrm{~mL})$ were added. The combined organic extracts were dried over $\mathrm{Na}_{2} \mathrm{SO}_{4}$ and the solvent was removed under reduced pressure. The crude residue was purified by flash column chromatography (silica gel, $n$-hexane/EtOAc, $5 \%$ ) to give $(E)$-4-styrylbenzonitrile $(3 \mathrm{~m})$ and 4-(1-phenylvinyl)benzonitrile $(4 \mathrm{~m}, 56 \mathrm{mg}$, ratio $90: 10,70 \%$ combined yield) as a white solid.

Method 3: To a stirred solution of $\mathrm{Pd}(\mathrm{OAc})_{2}(3.5 \mathrm{mg}, 0.016 \mathrm{mmol})$, glucose $(70 \mathrm{mg}$, $0.39 \mathrm{mmol})$ and 4-iodotoluene $(85 \mathrm{mg}, 0.39 \mathrm{mmol})$ in degassed acetonitrile / degassed water (1:3, $4 \mathrm{~mL})$ at rt were added 1-phenylethanol $(97 \mathrm{mg}, 0.79 \mathrm{mmol}$ ) and formic acid $(33 \mu \mathrm{L}, 0.87 \mathrm{mmol})$. The vial was sealed and the mixture was heated at $150{ }^{\circ} \mathrm{C}$ for $16 \mathrm{~h}$. The mixture was cooled to $\mathrm{rt}$ and water $(10 \mathrm{~mL})$ and dichloromethane $(10 \mathrm{~mL})$ were added. The combined organic extracts were dried over $\mathrm{Na}_{2} \mathrm{SO}_{4}$ and the solvent was removed under reduced pressure. The crude residue was purified by flash column chromatography (silica gel, $n$-hexane/EtOAc, $5 \%)$ to give $(E)$-4-styrylbenzonitrile $(3 \mathrm{~m})$ and 4-(1-phenylvinyl)benzonitrile $(4 \mathrm{~m}, 41$ $\mathrm{mg}$, ratio $90: 10,51 \%$ combined yield) as a white solid.

(E)-4-Styrylbenzonitrile (3m) 
${ }^{1} \mathrm{H}$ NMR $\left(400 \mathrm{MHz}, \mathrm{CDCl}_{3}\right): \delta 7.67-55(\mathrm{~m}, 6 \mathrm{H}), 7.44(\mathrm{t}, J=7.4 \mathrm{~Hz}, 2 \mathrm{H}), 7.37-7.33(\mathrm{~m}$ $1 \mathrm{H}), 7.24(\mathrm{~d}, J=16.4 \mathrm{~Hz}, 1 \mathrm{H}), 7.11(\mathrm{~d}, J=16.3 \mathrm{~Hz}, 1 \mathrm{H})$ ${ }^{13} \mathrm{C} \mathrm{NMR}\left(100 \mathrm{MHz}, \mathrm{CDCl}_{3}\right) \delta 141.9,136.3,132.5(2 \times \mathrm{C}), 132.4,128.9(2 \times \mathrm{C}), 128.7$, $126.93(2 \times \mathrm{C}), 126.88(2 \times \mathrm{C}), 126.7,119.1,110.6$ IR $\left(\mathrm{CHCl}_{3}\right): 3023,2920,2854,2223,1600,1503,972,823,756,689 \mathrm{~cm}^{-1}$ HRMS (APPI) $\mathrm{m} / \mathrm{z}$ calcd. for $\left[\mathrm{C}_{15} \mathrm{H}_{11} \mathrm{~N}\right]^{+}, 205.0886$; found 205.0890 .

(E)-4-Nitro-stilbene ${ }^{52}$ (3n), 1-Nitro-4-(1-phenylvinyl)benzene ${ }^{45}(4 n)$

Method 1: To a stirred solution of $\mathrm{Pd}(\mathrm{OAc})_{2}(3.5 \mathrm{mg}, 0.016 \mathrm{mmol})$, glucose (70 mg, $0.39 \mathrm{mmol}$ ) and 4-iodonitrobenzene (194 $\mathrm{mg}, 0.78 \mathrm{mmol}$ ) in degassed acetonitrile / degassed water $(1: 3,4 \mathrm{ml})$ at $\mathrm{rt}$ were added styrene $(87 \mu \mathrm{L}, 0.79 \mathrm{mmol})$. The vial was sealed and the mixture was heated at $150{ }^{\circ} \mathrm{C}$ for $16 \mathrm{~h}$. The mixture was cooled to $\mathrm{rt}$ and water $(10 \mathrm{~mL})$ and dichloromethane $(10 \mathrm{~mL})$ were added. The combined organic extracts were dried over $\mathrm{Na}_{2} \mathrm{SO}_{4}$ and the solvent was removed under reduced pressure. The crude residue was purified by flash column chromatography (silica gel, $n$-hexane/EtOAc, 5\%) to give (E)-1-nitrostilbene (3n) and 1-nitro-4-(1phenylvinyl)benzene (4n, $159 \mathrm{mg}$, ratio 92:8, 90\% combined yield) as a yellow solid.

Method 2: To a stirred solution of $\mathrm{Pd}(\mathrm{OAc})_{2}(3.5 \mathrm{mg}, 0.016 \mathrm{mmol})$, glucose $(70 \mathrm{mg}$, $0.39 \mathrm{mmol}$ ) and 4-iodonitrobenzene $(97 \mathrm{mg}, 0.39 \mathrm{mmol})$ in degassed acetonitrile / degassed water $(1: 3,4 \mathrm{~mL})$ at $\mathrm{rt}$ were added 1 -phenylethanol $(97 \mathrm{mg}, 0.79 \mathrm{mmol})$. The vial was sealed and the mixture was heated at $150{ }^{\circ} \mathrm{C}$ for $16 \mathrm{~h}$. The mixture was cooled to rt and water $(10 \mathrm{~mL})$ and dichloromethane $(10 \mathrm{~mL})$ were added. The combined organic extracts were dried over $\mathrm{Na}_{2} \mathrm{SO}_{4}$ and the solvent was removed under reduced pressure. The crude residue was purified by flash column chromatography (silica gel, $n$-hexane/EtOAc, $5 \%$ ) to give (E)-1-nitrostilbene (3n) and 1-nitro-4-(1-phenylvinyl)benzene ( $4 \mathrm{n}, 62 \mathrm{mg}$, ratio 90:10, 83\% combined yield) as a yellow solid.

Method 3: To a stirred solution of $\mathrm{Pd}(\mathrm{OAc})_{2}(3.5 \mathrm{mg}, 0.016 \mathrm{mmol})$, glucose $(70 \mathrm{mg}$ $0.39 \mathrm{mmol}$ ) and 4-iodonitrobenzene $(97 \mathrm{mg}, 0.39 \mathrm{mmol})$ in degassed acetonitrile / degassed water (1:3, $4 \mathrm{~mL})$ at rt were added 1-phenylethanol $(97 \mathrm{mg}, 0.79 \mathrm{mmol}$ ) and formic acid ( $33 \mu \mathrm{L}, 0.87 \mathrm{mmol})$. The vial was sealed and the mixture was heated at $150{ }^{\circ} \mathrm{C}$ for $16 \mathrm{~h}$. The mixture was cooled to $\mathrm{rt}$ and water $(10 \mathrm{~mL})$ and dichloromethane $(10 \mathrm{~mL})$ were added. The combined organic extracts were dried over $\mathrm{Na}_{2} \mathrm{SO}_{4}$ and the solvent was removed under reduced pressure. The crude residue was purified by flash column chromatography (silica gel, $n$-hexane/EtOAc, $5 \%$ ) to give (E)-1-nitrostilbene (3n) and 1-nitro-4-(1-phenylvinyl)benzene (4n, $19 \mathrm{mg}$, ratio $90: 10,22 \%$ combined yield) as a yellow solid.

\section{(E)-1-Nitrostilbene $(3 n)$}

$\left.{ }^{1} \mathrm{H} \mathrm{NMR} \mathrm{(400} \mathrm{MHz}, \mathrm{CDCl}_{3}\right): \delta 8.22(\mathrm{~d}, J=8.8 \mathrm{~Hz}, 2 \mathrm{H}), 7.64(\mathrm{~d}, J=8.8 \mathrm{~Hz}, 2 \mathrm{H}), 7.56(\mathrm{~d}$, $J=7.3 \mathrm{~Hz}, 2 \mathrm{H}), 7.42(\mathrm{t}, J=7.4 \mathrm{~Hz}, 2 \mathrm{H}), 7.36-7.32(\mathrm{~m}, 1 \mathrm{H}), 7.28(\mathrm{~d}, J=16.3 \mathrm{~Hz}, 2 \mathrm{H})$, $7.15(\mathrm{~d}, J=16.3 \mathrm{~Hz}, 2 \mathrm{H})$

${ }^{13} \mathrm{C} \mathrm{NMR}\left(100 \mathrm{MHz}, \mathrm{CDCl}_{3}\right) \delta 146.8,143.9,136.2,133.3,128.9(2 \times \mathrm{C}), 128.8,127.0$ $(2 \times \mathrm{C}), 126.9(2 \times \mathrm{C}), 126.3,124.2(2 \times \mathrm{C})$

IR $\left(\mathrm{CHCl}_{3}\right): 3089,2920,1593,1569,1505,1336,1105,849,692 \mathrm{~cm}^{-1}$ HRMS (APPI) $\mathrm{m} / z$ calcd. for $\left[\mathrm{C}_{14} \mathrm{H}_{11} \mathrm{NO}_{2}\right]^{+}, 225.0784$; found 225.0778 .

This work was supported by the University of Nottingham, the EPSRC (FirstGrant EP/J003298/1) and the University of Huddersfield (PhD studentship for T.W.B).

The authors thank Dr Christopher Parmenter (Nanosight) and Dr Emily Smith (XPS) for their efforts.

YES

YES

References

${ }^{1}$ For recent examples, see: (a) G. Cheng, P. Wang and J.-Q. Yu, Angew. Chem. Int. Ed., 2017, 56, 8183-8186. (b) X. Bao, Q. Wang and J. Zhu, Angew. Chem. Int. Ed., 2017, 56, 9577-9581. (c) X. Qi, P. Chen and G. Liu, Angew. Chem. Int. Ed., 2017, 56, 9517-9521.

2 (a) R. F. Heck, Acc. Chem. Res., 1979, 12, 146-151. (b) A. B. Dounay and L. E. Overman, Chem. Rev., 2003, 103, 2945-2963.

${ }^{3}$ (a) W. M. Czaplik, M. Mayer, J. Cvengros and A. J. von Wangelin, ChemSusChem, 2009, 2, 396-417. (b) D. S. McGuinness, K. J. Cavell, B. W. Skelton and A. H. White, Organometal., 1999, 18, 1596-1605. (c) L. Yin, J. Liebscher, Chem. Rev., 2007, 107, 133-173. (d) I. P. Beletskaya and A. V. Cheprakov, Coord. Chem. Rev., 2004, 248, 2337-2364.

${ }^{4}$ (a) J. Dupont, R. F. de Souza and P. A. Z. Suares, Chem. Rev., 2002, 102, 3667-3691. (b) C.-J. Li, Chem. Rev., 2005, 105, 3095-3165. (c) M. Lamblin, L. Nassar-Hardy, J.-C. Hierso, E. Fouquet and F.-X. Felpin, Adv. Syn. Catal., 2010, 352, $33-79$.

5 (a) C. O. Kappe, Angew. Chem. Int. Ed., 2004, 43, 6250-6284. (b) G. C. Fu, Acc. Chem. Res., 2008, 41, 1555-1564. (c) A. J. Carmichael, M. J. Earle, J. D. Holbrey, P. B. McCormac and K. R. Sneddon, Org. Lett., 1999, 1, 997-1000. (d) R. R. Deshmukh, R. Rajagopal and K. V. Srinivasan, Chem. Comm., 2001, 1544-1545

${ }^{6}$ (a) J. G. Taylor, A. V. Moro and C. R. D. Correia, Eur. J. Org. Chem., 2011, 1403-1428. (b) I. P. Beletskaya and A. V. Cheprakov, Chem. Rev., 2000, 100, 3009-3066.

${ }^{7}$ (a) Z. Li, C. Gelbaum, J. S. Fisk, B. Holden, A. Jaganathan, G. T. Whiteker, P. Pollet and C. L. Liotta, J. Org. Chem., 2016, 81, 8520-8529. (b) M. L. Kantam, P. V. Reddy, P. Srinivas and S. Bhargava, Tetrahedron Lett., 2011, 52, 4490-4493.

8 (a) A. S. Saiyed and A. V. Bedekar, Tetrahedron Lett., 2010, 51, 6227-6231. (b) G. Meng and M. Szostak, Angew. Chem. Int. Ed., 2015, 54, 14518-14522. 9 J. Ruan, X. Li, O. Saidi and J. Xiao, J. Am. Chem. Soc., 2008, 130, 2424-2425.

${ }^{10}$ For a related example of dehalogenative cross-coupling, see: A. K. Jha, S. Kishor and N. Jain, RSC. Adv., 2015, 5, 55218-55226.

${ }^{11}$ P. Colbon, J. H. Barnard, M. Purdie, K. Mulholland, I. Kozhevnikoc and J. Xiao, Adv. Syn. Catal. 2012, 354, 1395-1400.

${ }^{12}$ For the dehydration of aryl alcohols in Mizoroki-Heck reactions in ionic liquids, see: R. Kumar, A. Shard, R. Bharti, Y. Thopate and A. K. Sinha, Angew. Chem. Int. Ed., 2012, 51, 2636-2639.

${ }^{13}$ A. Shad, K. Rawat, A. K. Sinha, Y. Padwad and D. Kumar, Eur. J. Org. Chem., 2016, 5941-5949.

${ }^{14}$ N. H. Andhare, Y. Thopate, Shamsuzzama, L. Kumar, T. Sharma, M. I. Siddiqi, A. K. Sinha and A. Nazir, Tetrahedron, 2018, 74, 1655-1667.

${ }^{15}$ J. K. F. Buijink, J. P. Lange, A. N. R. Bos, A. D. Horton and F. G. M. Niele, in: S. T. Oyama ed, Mechanisms in Homogenous and Heterogeneous Epoxidation Catalysts, Elsevier B. V., Amsterdam, 2008, 355.

${ }^{16}$ F. Cavani and F. Trifiró, Appl. Catal A: Gen., 1995, 133, 219-239.

${ }^{17}$ (a) J. K. Ward and J. B. Gardner, US Pat., 4,161,554, 1979. (b) Chevron Phillips Chemical Company LP, Safe handling and storage of styrene monomer, 2010.

${ }^{18}$ R. Tornero-Velez et. al., Lancet Oncol. 2018 DOI:/10.1016/ S1470-2045(18)30316-4

${ }^{19}$ (a) J. E. Camp, J. J. Dunsford, E. P. Cannons, W. J. Restorick, A. Gadzhieva, M. W. Fay and R. J. Smith, ACS Sustainable Chem. Eng., 2014, 2, 500505. (b) A. Monopoli, V. Calò, F. Ciminale, P. Cotugno, C. Angelici, N. Cioffi and A. Nacci, J. Org. Chem., 2010, 75, 3908-3911.

${ }^{20}$ For a review, see: S. Kyne and J. E. Camp, ACS Sustainable Chem. Eng., 2017, 5, 41-48. 
${ }^{21}$ J. E. Camp, J. J. Dunsford, O. S. G. Dacosta, R. K. Blundell, J. Adams, J. Britton, R. J. Smith, T. W. Bousfield and M. K. Fay, RSC Adv., 2016, 6, 1611516121.

${ }^{22}$ S. S. Stahl, Science, 2005, 309, 1824-1826.

${ }^{23}$ See the ESI for full details.

${ }^{24}$ J. Ruan and J. Xiao, Acc. Chem. Res., 2011, 44, 614-626.

${ }^{25}$ (a) L. Qin, X. Ren, Y. Lu, Y. Li and J. Zhou, Angew. Chem. Int. Ed., 2012, 51, 5915-5919. (b) L. Qin, H. Hirao and J. Zhou, Chem. Comm., 2012, 49, 10236-10238.

${ }^{26}$ F. I. McGonagle, H. F. Sneddon, C. Jamieson and A. J. B. Watson, ACS Sustainable Chem. Eng., 2014, 2, 523-532.

${ }^{27}$ For recent examples of Mol. E\% calculations, see: (a) D. Malferrari, N. Armenise, S. Decesari, P. Galletti and E. Tagiavini, ACS Sustainable Chem. Eng., 2015, 3, 1579-1588 (b). N. R. Agrawal, S. P. Bahekar, P. B. Sarode, S. S. Zade and H. S. Chandak, RSC Adv., 2015, 5, 47053-47059. (c) B. T. Reid and S. M. Reed, Green Chem., 2016, 18, 4263-4269. (d) L. Mistry, K. Mapesa, T. W. Bousfield and J. E. Camp, Green Chem., 2017, 19, $2123-2128$.

${ }^{28}$ S. Rohilla, P. Pant and N. Jain, RSC Adv., 2015, 5,31311-31317.

${ }^{29}$ A. F. Littke, G. C. Fu, J. Am. Chem. Soc. 2001, 123, 6989-7000.

${ }^{30}$ (a) M. Comotti, C. D. Pella, E. Falletta, M. Rossi, M. Adv. Synth. Catal. 2006, 348, 313-316. (b) S. Panigrahi, S. Kundu, S. K. Ghosh, S. Nath, T. Pal, Colloids Surf. A 2005, 264, 133-138.

${ }^{31}$ A. Abbadi, H. van Bekkum, J. Mol. Catal. A: Chem. 1995, 97, 111-118.

${ }^{32}$ P. R. Rich, Biochem. Soc. Trans. 2003, 31, 1095-1105.

${ }^{33}$ M. T. Reetz, E. Westermann, Angew. Chem. Int. Ed. 2000, 39, 165-168.

${ }^{34}$ K. Fujimori, Aust. J. Chem. 1977, 30, 685-687.

${ }^{35}$ V. Filipe, A. Hawe and J. Jiskoot, Pharm. Res., 2010, 27, 796-810.

${ }^{36}$ K. Schätzel, M. Drewel and J. Ahrens, J. Phy.: Condens. Matter, 1990, 2, SA393-SA398.

${ }^{37}$ G. S. Roberts, D. Kozak, W. Anderson, M. F. Broom, R. Vogel and M. Trau, Small, 2010, 6, 2653-2658.

${ }^{38}$ Z.-Y. Peng, F.-F. Ma, L.-F. Zhu, X.-M. Xie and Z. Zhang, J. Org. Chem., 2009, 74, 6855-6858.

${ }^{39}$ D. Ganapathy and G. Sekar, Org. Lett., 2014, 16, 3856-3859.

${ }^{40}$ S. Fu, N.-Y. Chen, X. Liu, Z. Shao, S.-P. Luo and Q. Liu, J. Am. Chem. Soc., 2016, 138, 8588-8594.

${ }^{41}$ C. Lei, Y. J. Yip and J. S. Zhou, J. Am. Chem. Soc., 2017, 139, 6086-6089.

${ }^{42}$ T. Niwa and M. Nakada, J. Am. Chem. Soc., 2012, 134, 13538-135.41.

43 J. Tang, D. Hackenberger and L. J. Goossen, Angew. Chem. Int. Ed., 2016, 55, 11296-11299.

44 G. Cahiez, O. Gager and F. Lecomte, Org. Lett., 2008, 10, 5255-5256.

${ }^{45}$ S. Agasti, A. Dey and D. Maiti, Chem. Commun., 2016, 52, 12191-12194.

46 J.-Y. Yu, R. Shimizu and R. Kuwano, Angew. Chem. Int. Ed., 2010, 49, 6396-6399.

${ }^{47}$ E. Alacid and C. Nájera, J. Org. Chem., 2008, 73, 2315-2322.

48 J.-J. Zhong, Q. Liu, C.-J. Wu, Q.-Y. Meng, X.-W. Gao, Z.-J. Li, B. Chen, C.-H. Tung and L.-Z. Wu, Chem. Commun., 2016, 52, $1800-1803$.

49 A. Gonzalez-de-Castro and J. Xiao, J. Am. Chem. Soc., 2015, 137, 8206-8218.

${ }_{50}$ M. H. Hansmann, A. López-Andarias, E. Rettenmeier, C. Egler-Lucas, F. Rominger, A. S. L. Hashmi and C. Romero-Nieto, Angew. Chem. Int. Ed., 2016, 55, 1196-1199.

${ }^{51}$ G. Wu, X. Zhao, W. Ji, Y. Zhang and J. Wang, Chem. Commun., 2016, 52, 1961-1963.

${ }^{52}$ H. F. Sore, D. T. Blackwell, S. J. MacDonald and D. R. Spring, Org. Lett., 2010, 12, 2806-2809. 